\title{
La invención del Sacromonte: How and Why Scholars Debated about the Lead Books of Granada for Two Hundred Years
}

\begin{abstract}
At the end of the sixteenth century, a number of relics and artefacts were discovered in Granada, Spain. They included what became known as the Lead Books of the Sacromonte, twenty-one written artefacts made of circular lead leaves engraved in archaic Arabic characters. The authorship was attributed to some Arab disciples of St James the Greater considered to be the first evangelisers of the Iberian Peninsula. The texts, the materiality and the circumstances of the discoveries fuelled a debate surrounding their authenticity that lasted more than two centuries, a debate so fierce and controversial that not even papal condemnation in 1682 was able to stop it. Soon after the discoveries were made public, scholars highlighted the many contradictions and errors of a historical, linguistic and theological nature present in the texts, identifying members of the local Morisco community as possible forgers. This article focuses on how the scholarly community of the sixteenth and seventeenth centuries handled these findings and looks at the methods employed by the scholars to evaluate the authenticity of the artefacts. It will also look at how the particular interests of the various authorities involved influenced the acceptance or dismissal of relevant academic results.
\end{abstract}

Many interesting objects were found in Granada towards the end of the sixteenth century. These included a box filled with relics and a piece of written parchment, which were discovered in the rubble of the Torre Vieja, the old minaret of the Great Mosque. Other remains and peculiar written artefacts were excavated from a complex of caves in Mount Valparaíso on the outskirts of the city. The relics found in the caves were attributed to St Caecilius, St Ctesiphon and St Hesychius - martyrs, companions of St James ${ }^{1}$ and first evangelisers of the Iberian

1 The figure of St James is very important in Spain and many legends have been created around this character. In one of these, he is considered to be the first evangeliser of the Iberia Peninsula.

Ә Open Access. (C) 2020 Cécilia Colini, published by De Gruyter. (cc) BY-NC-ND This work is licensed under the Creative Commons Attribution-NonCommercial-NoDerivatives 4.0 International License.

https://doi.org/10.1515/9783110714333-011 
Peninsula - thanks to the information engraved in Latin on lead sheets found together with the remains. The area where the find was made was renamed Sacromonte (Holy Mountain) once the artefacts were identified as relics.

Twenty-one lead books were also found in addition to these lead sheets: the volumes are made of a number of small, circular leaves of lead engraved on both sides, each inside a sort of cover made of folded lead. The titles of the books are inscribed on the covers in Latin, while the circular leaves are written in Arabic. Both types of writing look very archaic. After the discoveries were made, the inhabitants of Granada experienced an unprecedented religious fervour: not only did the city possess some relics of its own now, but the relics themselves included the remains of St Caecilius, the first bishop of Granada, which corresponds to the Roman town of Ilíberis. Moreover, the texts testified that Ilíberis was the first town evangelised by St James, thus making Granada one of the most important Catholic cities in Spain, contending the leadership of Santiago de Compostela and Toledo.

Since the use of the Arabic language was forbidden by royal decree in 1567 as it was believed to be a sign of Muslim identity, such strange finds were extremely controversial. Not only were the books written in Arabic, but in some passages, St Mary is said to consider the language worthy of the word of God. Moreover, according to the biographies on the lead leaves, both Caecilius and Ctesiphon were Arabs. Finally, Christian readers felt that the message transpiring from numerous translations into Spanish was tainted by Islamic concepts.

Contemporary sources described the finds as the invencion of the Sacromonte, which is the vernacular form of the medieval hagiographical inventio. Like its Latin counterpart, this word conveys both the meaning of discovery and that of creation. ${ }^{2}$ Following their discovery and right up to the end of the eighteenth century - that is, almost a hundred years after the books (not the relics) were declared heretical by Pope Innocent XI in 1682 - many, many pages were written expressing arguments in favour of or against the authenticity of the finds. The materials are now unanimously considered forgeries by scholars and are mostly seen as the last attempt by the Morisco community to be accepted and

In others, his body was transferred to Spain either by a miracle or by seven of his disciples, in this case combining the figure of St James with the medieval legend of the Apostolic Men (see below, n. 13). He played an important role during the Reconquista when he got the epithet of Santiago Matamoros (the Moor-slayer) due to his miraculous appearance during the legendary battle of Clavijo in 844. He was the patron saint of Spain from the 1620 s until 1760 when Our Lady of the Immaculate Conception was declared patroness of the country; St James remained patron of the Spaniards. See Martínez Medina 2006, 93-96; 2015, 58-61.

2 Harries 2007, XIV. 
recognised by Spanish society. The debate concerning the production and reception of the forgeries is still going, however, and is far from reaching a conclusion in the near future. This is due to the exceptional circumstances in which the entire matter originated and evolved, the numerous actors who played a role in it, the many interests involved and also the fact that there is still no scholarly edition of the texts. ${ }^{3}$ In fact, the original leaves were kept hidden in the Vatican from the point where they were banned in 1682 until the year 2000 when they were returned to Sacromonte Abbey. Since then, accessing them has been difficult at

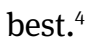

Despite these obstacles, numerous researchers have published articles on the Lead Books over the last few decades, all looking at the Sacromonte affair from different angles: the relation between the textual messages and Catholic and Islamic religion, the many protagonists and scholars involved in the affair, the materiality of the various objects, the social context surrounding the production and reception of the forgeries, and even studies focusing on Orientalism in Spain. ${ }^{5}$ This paper will evaluate all this data to explore the subject from a new point of view: how the scientific community received the finds in the sixteenth and seventeenth century. First of all, however, it is necessary to outline the context that led to the production of the forgeries, their discovery and the behaviour of the main characters involved. This will put into perspective the positions that were taken by the scholars involved to evaluate the authenticity of the relics, the methods they employed and the credit they were paid, depending on the various competing interests at play. For the sake of readability, both the chronology of

3 There are however, many translations and editions based on secondary literature, that is, on the copies, engravings and translation made between the sixteenth and eighteenth century during the process of trying to authenticate the texts. A complete edition and translation of the Arabic texts of the Lead Books will be the outcome of the studies now being conducted by the Dutch scholars Pieter van Koningsveld and Gerard Wiegers. They have already edited some of the books and presented the current state of their project on 19 March 2019 in Granada; see van Koningsveld/Wiegers 2019.

4 The journalist Alejandro V. García argued about the Archbishop's motives for impeding the study and investigation of the Lead Books on the pages of webislam.com in April 2007. García even suggested the possibility that the returned artefacts may not have been the originals, but just copies; see Drayson 2013, 6-7. García's articles pages are not accessible any longer as the online journal changed its name and domain into Verislam.com.

5 A summary of these studies highlighting the new approaches can be found in Álvarez de Morales 2003-2004. The most recent and comprehensive works on the topic, which are also the main sources of this paper, are these: Barrios Aguilera/García-Arenal 2006, Harris 2007, GarcíaArenal/Rodríguez Mediano 2010 and 2013, Barrios Aguilera 2011, Vega García Ferrer et al. 2011, Drayson 2013 and Martínez Medina 2015. 
the finds and the biographies of the scholars mentioned have been included in the appendix.

\section{The context}

The events leading to the production of the Sacromonte relics and the reasons for their controversial value are to be found in how the Reconquista affected the area of al-Andalus and the population inhabiting it. ${ }^{6}$

The Reconquista ended with the fall of Granada in 1492. The treaty's terms were very generous to the Muslims, who were even allowed to maintain their faith, although the pact was only respected for the first few years under the guidance of the first archbishop of Granada, Hernando de Talavera. He pursued the evangelisation of the city through a series of measures intended to persuade the Islamic community to assimilate, which included preaching in the Arabic language. The situation changed when forced mass conversions were ordered by Cardinal Francisco Jiménez de Cisneros in 1499 and 1501 and those who refused to be baptised were expelled or even executed. Those who converted were called Moriscos to differentiate them from the Muslims, who were called Moros ('Moors'). Despite the conversions, the Moriscos were always treated with suspicion by the Old Christians (the Spaniards and those who converted before the fall of Granada) since the mass conversions were not perceived as genuine conversions to the Christian faith. In fact, the Moriscos were accused of practising their original faith in secret and of conspiring with Moroccans and Turks against the monarchy in order to retake al-Andalus; the fact that they did not abandon their previous traditions and customs or their language and books was sufficient proof of this. As a result, restrictive measures against the culture of the Moriscos started to be introduced around the 1520s, culminating in the royal decree of 17 November 1566 (ratified one year later), in which use of the Arabic language was prohibited as well as Arabic names, Morisco clothes and symbols, their music and bathhouses. Their rights to carry weapons and have servants and slaves were also lost. Moreover, the pressure and control that the Inquisition exercised on Moriscos increased.

6 The main sources of this chapter are Barrios Aguilera/García-Arenal 2006, Harris 2007, GarcíaArenal/Rodríguez Mediano 2010 and 2013, Barrios Aguilera 2011, Drayson 2013 and Martínez Medina 2015. 
Such oppressive measures led members of the Morisco community to express their consternation in different ways: the elite and in general the citizens of Granada fought the measures in a peaceful way, mostly by sending representatives to the authorities, filing complaints and writing essays against the reforms, while the population of rural and mountainous areas in particular started a rebellion that ended in the Alpujarras War, as it came to be known (1568-1571). This civil war was extremely ferocious and bloody; even though the rebels could count on some help from Berbers and Turks, they were still outnumbered, ill-equipped and had little or no military training. When the rebellion was eventually suppressed, Granada was in a shambles: the economic and social infrastructure of the area was badly damaged, the current harvest was destroyed and more than half of the Morisco population was expelled from the region, adding a big demographical drop to the already dire situation. The Spanish administration tried to repopulate the area by giving land previously owned by Moriscos to settlers from all over Spain, but the difficult conditions there did not attract enough volunteers, resulting in a much slower recovery process than it had hoped for. Meanwhile, the city of Granada lost the prominent political position it had enjoyed under the rule of the Catholic monarchs, as exemplified by Philip II's decision in 1573 to remove the remains of his deceased wife and of Charles V's family from the Royal Chapel of Granada.

In 1580 there were still around 10,000 Moriscos in the territory of the former realm of Granada. Many of them returned to the area after their expulsion, but a good number of them were descendants of Moors who had converted to Christianity before the conquest of Granada, people who were legally considered to be Old Christians and who were therefore never expelled to begin with. Among them were clergymen, doctors and translators; for them, knowing Arabic was convenient, if not necessary, and they proved valuable to the Crown in maintaining diplomatic relations with the rulers of Morocco and the Ottoman sultan. During the Alpujarras War, they were even employed to spy on the rebels and forge letters and documents. They were tolerated for these reasons, although never fully trusted, and always needed to prove their loyalty and faith by showing irreproachable conduct. Landowners and noblemen of Nasrid origin - thus part of the last Moorish Muslim dynasty ruling the Emirate of Granada - were also considered Old Christians. Members of these families converted to Christianity and were assimilated into the Christian aristocracy by the end of the Reconquista, playing a fundamental role in the process of integrating the kingdom of Granada into the Spanish state. Consequently, they enjoyed special economic benefits and tax exemptions. They preferred the epithet 'natives of Granada' (nativos de Granada) over Moriscos to define themselves and considered themselves 
Christian Arabs. They believed they had the same right to gain honour and power as any other aristocrat. Their position was severely diminished after the Reconquista and especially in the wake of the Alpujarras War.

It is among this circle of privileged Moriscos and Old Christians of Arab descent that the defence of the cultural identity of the minority took place, especially in families like the Muley Fez, Núñes Muley and Granada Venegas. They developed their ideas at the literary gatherings organised in the house of the Granada Venegas and spread them by writing essays and treatises focused on two main points: the separation of culture from faith and the distinction of the 'good' Moriscos - those who integrated socially and religiously despite maintaining their cultural identity - from the 'bad' ones, such as the rebels involved in the Alpujarras War. ${ }^{7}$ Moreover, they highlighted the noble origin of their families (which was indispensable to get the hidalguía, i.e. the status of aristocrats in Spain) and for this reason they produced family trees and histories of their lineages based on both genuine and forged documents and legends. These presented the Moriscos as heroes of chivalric romances, as the descendant of Goths or as crypto-Christians during the Muslim era. ${ }^{8}$

This is most likely the cultural context in which the Sacromonte forgeries were conceived, as the goals appear similar: in the Lead Books, Arabic is considered a Christian language and the Arabs are presented as the first group converted to Christianity in the Iberian Peninsula, implicitly suggesting that the Moriscos present in Spain in the fifteenth century were the descendants of these first converts. A very similar pattern of cultural resistance by way of rewriting history can also be observed in other communities and minorities, perfect examples being the Marranos of Toledo and the forgeries and inventions of Jeronimo Román de la Higuera, a Jesuit who tried to build a glorious and sacred past for his

7 See the position of Alonso Granada Venegas in his letters to Diego Hurtado de Mendoza concerning the Alpujarras War, for example. These letters highlight the oppression and discrimination suffered by Moriscos. In his Memorial, Francisco Núñez Muley emphasised the presence of Christian Arabs in Syria and Egypt who were not discriminated by the language they spoke. Perez de Hita stated in Guerras Civiles that the Moriscos who decided to remain in Spain wanted to assimilate and should therefore have been attributed the same status they had had before the fall of Granada. See García-Arenal 2006a, 62-74.

8 See Origen de la casa de Granada, for example, written for the Granada Venegas family, Las lágrimas de Angelica written for the Dukes of Osuna by Luis Barahona de Soto, and La historia verdadera del rey Don Rodrigo by Miguel de Luna. García-Arenal 2006a, 69-76; GarcíaArenal/Rodríguez Mediano 2013, 157-165. 
city, promote the integration of his community and embellish his own genealogy. ${ }^{9}$

Despite all these efforts, the Moriscos were definitively expelled from Spain between 1609 and 1611. However, this final expulsion did not affect any of the protagonists of the Sacromonte matter or the noble families of Nasrid origin, suggesting that their ideas influenced Spanish society to some extent. ${ }^{10}$

\section{The events}

The story started on 18 May 1588 when the Torre Vieja - the old minaret converted to a bell tower - was demolished in order to make space for the construction of the Cathedral. A lead box was found among the rubble, containing an image of St Mary dressed in an Egyptian way, a triangular piece of cloth later attributed to the veil of St Mary, a bone later attributed to St Stephen, and a piece of written parchment (Fig. 1). ${ }^{11}$

The parchment contains a table divided into two sections: the first one contains squares filled with Latin and Greek characters, with one character per square, while the second one sports rectangular spaces filled with Arabic words, with one or two words per space. The characters and words are alternately written in red or black ink, so if one space contains red ink, the next one contains black. There are some irregularities, however. The table is introduced and followed by Arabic text, with a signature at the bottom and a few notes in the left-hand margin. There is a note in Latin in the margin at the bottom left, which was the first thing to be understood due to the language skills of the first readers. It is a report by Patricius the presbyter about the imminent martyrdom of St Caecilius, the contents of the lead box and how he hid it in the Turpiana Tower, which was supposedly the original name of the tower before it was converted into a minaret.

9 One example of his writing is the Chronicon attributed to Flavio Lucio Dextro, a collection of fictional stories presented as historical facts. In one of the reports, it is narrated that the Jewish community present in Toledo at the time of Christ asked the apostles for evangelisation, so it is thanks to them that St James arrived in Spain; see Ecker 2002, 369-372; García-Arenal/Rodríguez Mediano 2013, 195-224.

10 Álvares de Morales 2002-2003, 736.

11 For an exhaustive description of the parchment, see van Koningsveld/Wiegers 2003. 


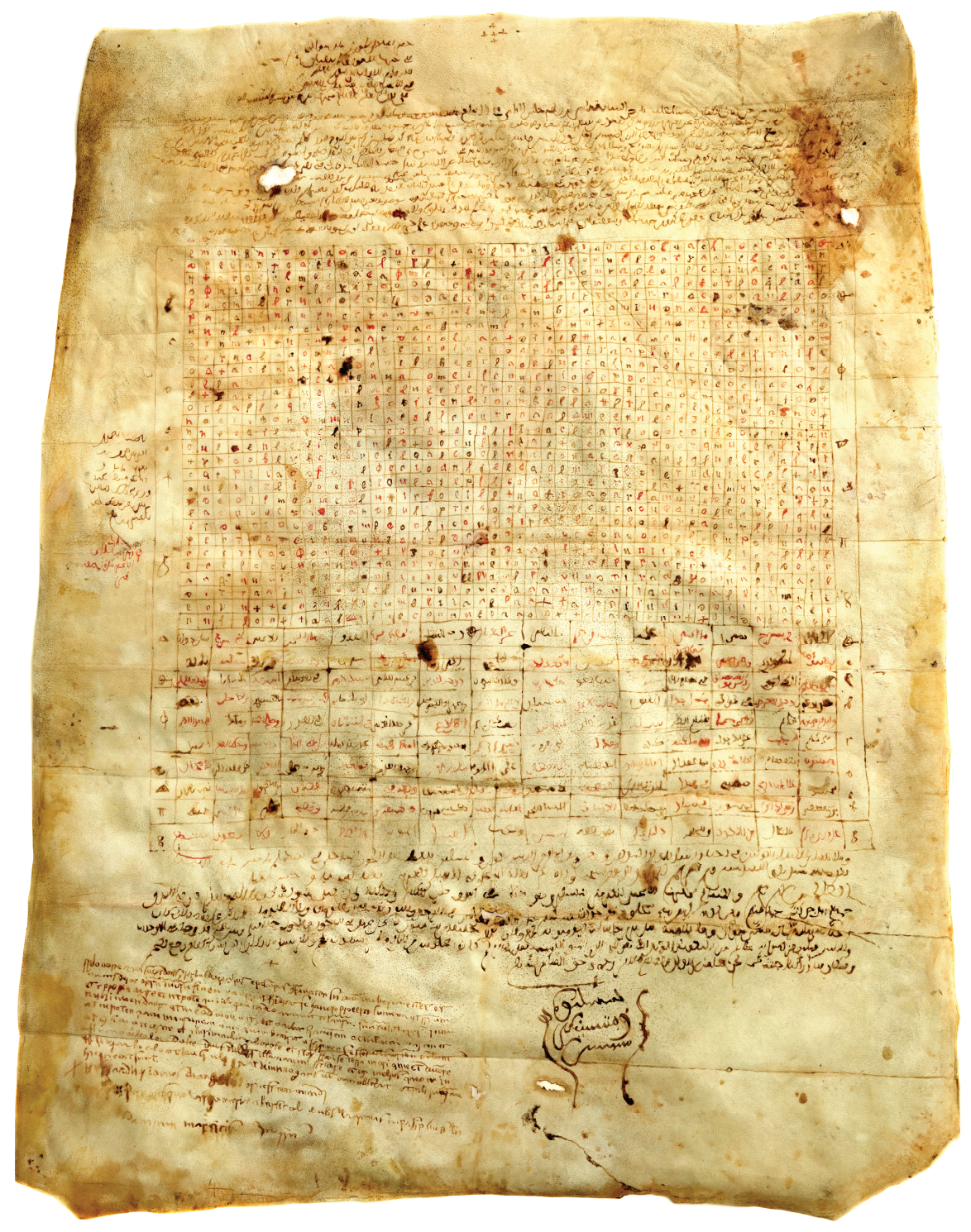

Fig. 1: Parchment from the Turpiana Tower; ( $)$ Reproduced by kind permission of the Archivo Abadía del Sacro Monte de Granada.

All the texts were then deciphered and translated by Miguel de Luna under the supervision of Francisco López Tamarid and were separately translated by Alonso del Castillo as well, although the latter could not interpret them 
completely. The translators, who were both doctors and thus part of the Morisco elite, were later accused of being the authors of the parchment (and of other fake artefacts that were subsequently discovered, too). ${ }^{12}$ The decrypted text of the first part of the table revealed a prophecy by St John, translated by St Caecilius into Spanish, and the second part contained St Caecilius's commentary on the prophecy in Andalusian Arabic. The advent of Islam and of the Reformation, the coming of the Antichrist and the beginning of the Final Judgement were all predicted in the prophecy. The notes following the table were interpreted as conclusive remarks made by St Caecilius, who signed it in a way usually transcribed as 'Caecilius Obispus Granatensis'. It is important to note that the figure of the first bishop of Granada, St Caecilius, and the story of his lost relics only came to people's attention a few years before the aforementioned discoveries thanks to Pedro Guerra de Lorca: in 1584, he wrote La Historia de la vida y martirio de San Çecilio y sus seis compañeros llamados los apóstoles de nuestra Hespaña, reporting the medieval legend of the Seven Apostolic Men, the first evangelisers of Spain. ${ }^{13}$

The miraculous finds - both the box and the relics had a persistent floral scent - obtained the immediate approval of the population and of the local church in the person of Juan Méndez de Salvatierra, Archbishop of Granada. He died soon after, however, and the successor appointed in 1589, Pedro Vaca de Castro y Quiñones, was interested, but sceptical. Before pursuing the authentication of the relics, he had them evaluated by a number of experts.

In the same years, two treasure hunters were chasing rumours about an abandoned gold mine on Mount Valparaíso, based on the directions found in a diary

12 Both historical documents and modern research seem to corroborate this hypothesis.

13 The manuscript in which the text is preserved is now in Madrid, Biblioteca Nacional de España MS 1499; García-Arenal/Rodríguez Mediano 2013, 174. The legend of the Seven Apostolic Men was created around the seventh to eighth century. According to the legend, seven men (Torquatus, Caecilius, Ctesiphon, Euphrasius, Indaletius, Hesychius and Secundius) were ordained clerics by St Peter and St Paul and then sent to Spain. When they were in Guadix, they were recognised as Christians during the celebrations in honour of the Capitoline triad and were chased to the river by the pagan population. The Christians managed to cross the bridge, but it miraculously collapsed when the pagans tried to cross it. This event converted a noblewoman called Luparia, who then helped the men to hide and continue their journey for the conversion of the Iberian Peninsula. In another version of this legend, the Apostolic Men were disciples of St James who were sent to transfer the remains of the Apostle to Spain. Once in Galicia, they asked a noblewoman, Luparia, to give them a pagan temple that she possessed in order to bury their master, but she reported them to the King. They were miraculously saved again when their pursuers were killed by the destruction of a bridge or the collapse of part of the caves where the Christians were hiding; this account varies according to which version one reads. Luparia is then converted and offers the temple to the Christians. See Martínez Medina 2015, 57-60. 
obtained by a prison convict. On 21 February 1595, in a cave blocked by a heavy stone, they found some objects and a lead sheet indicating that the burnt body of a martyr had been left there. The sheet was written in Latin, but used strange characters that the Jesuit Isidro García, ${ }^{14}$ the first translator of this text, identified as Spanish-Baetic, thus implying that this peculiar script was developed in Hispania Baetica - the Roman province approximately corresponding to modern Andalusia. A report about this find reached the Archbishop, who then assigned two of his men to conduct an excavation. The news spread fast, though, and the population fell into a state of apprehension also incited by the declarations of Isidro García, who suggested there was a relation between the Valparaíso caves and the catacombs recently found in Rome. All sorts of people, from peasants to nobles, gathered at the site and participated in the digging. Ashes, bones and lead sheets continued to be found: the texts mentioned the martyrs Ctesiphon, Hesychius and Caecilius, disciples of St James, and talked about the Arabic origin of Ctesiphon and Caecilius, about their activity as writers, and mentioned some of the titles of the Lead Books that were about to be found. The books were made of circular lead leaves varying between 6 and $15 \mathrm{~cm}$ in diameter and engraved on both sides in peculiar Arabic characters called 'Solomonic' at the time of their discovery, which displayed some archaic features (see Figs. 2-3). The leaves were held together by a lead thread passing through a small hole on the margin and were placed inside a folded lead cover inscribed in Latin (Fig. 4). They continued to be dug out of the cave until 1599, ultimately amounting to a total of 21 units. ${ }^{15}$
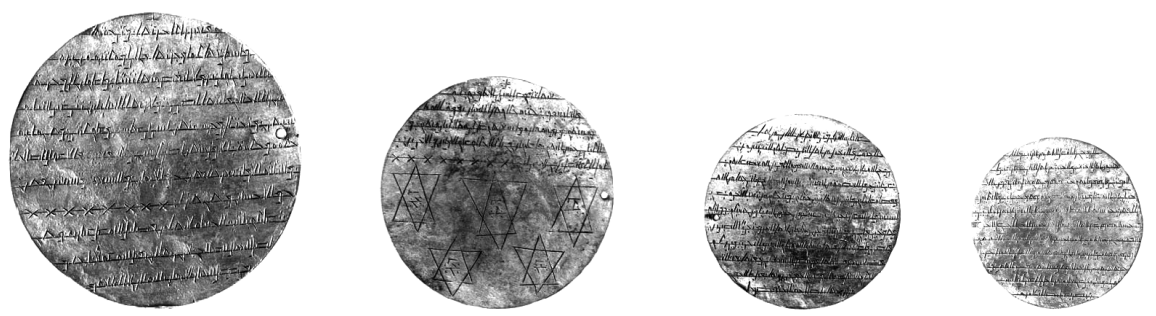

Fig. 2: Dimensions of the Lead Books.

14 Isidro García (1566-1604) was a teacher of rhetoric at Granada's Jesuit College; Harris 2007, 162.

15 See Appendix 1 for a complete list of the finds, including the titles of the books and the date of their discovery. 

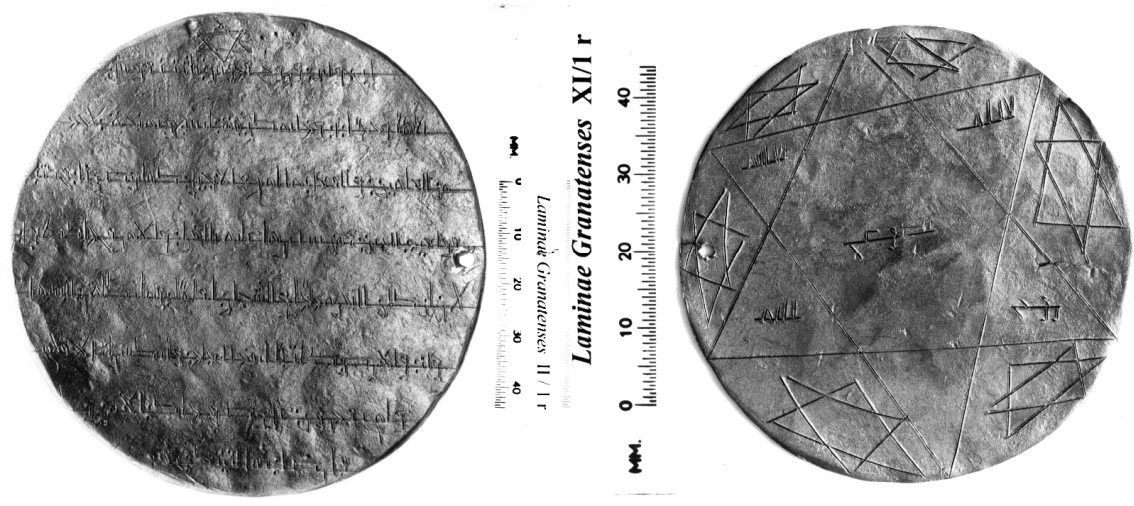

Fig. 3: Examples of the Lead Books; on the left, On the Essence of God, fol. 3r, Archivo Abadía Sacro Monte Granada, Laminae Granatenses II/1r; on the right, Book of Sayings on Faith, fol. 1r, Archivo Abadía Sacro Monte Granada, Laminae Granatenses XI/1r.

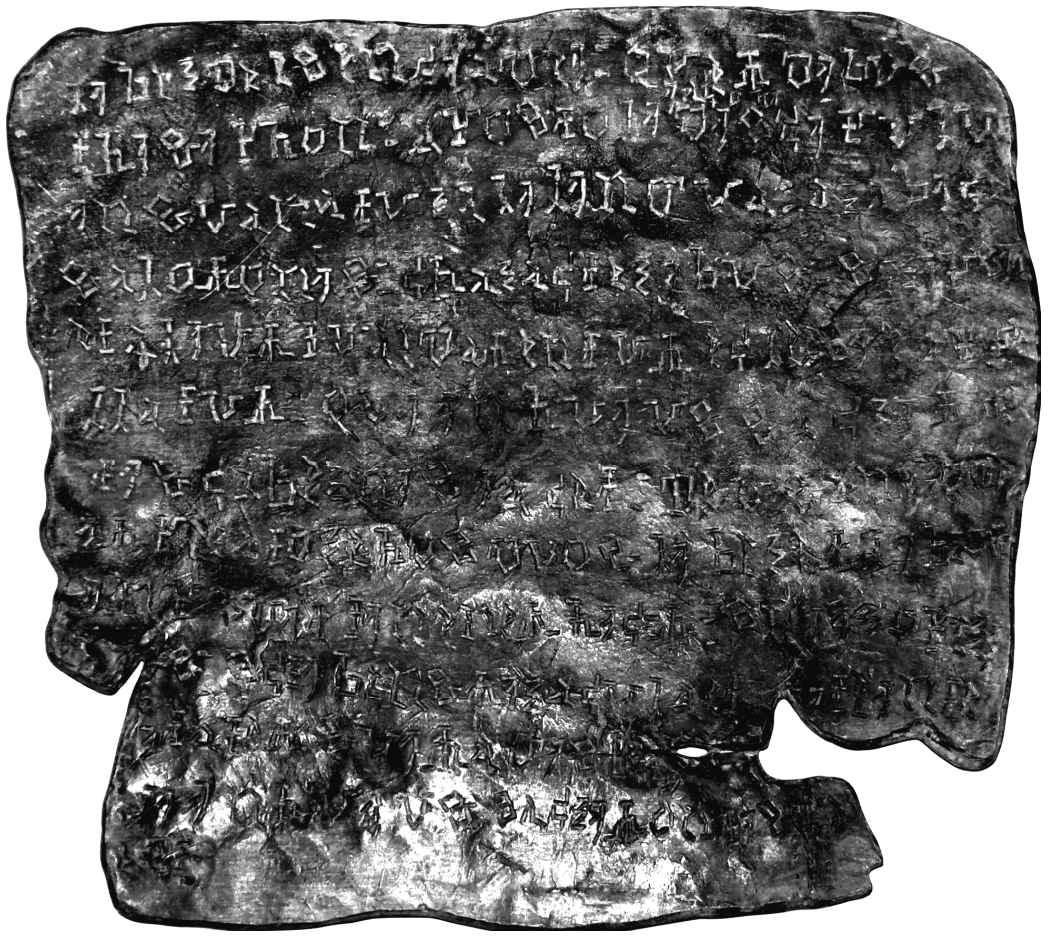

Fig. 4: Cover of the Lead Book The Fundamentals of the Faith with Latin characters; $\odot$ Figs 2, 3 and 4: Reproduced by kind permission of the Archivo Abadía del Sacro Monte de Granada. 
The devotional fervour of the population was now at its apex. After the discoveries, pilgrims visited the holy caves almost daily and votive crosses were put up over the area, which was also renamed Sacromonte. Archbishop Pedro de Castro immediately understood how important the relics must have been to a community without a Christian history and saints. As the qualification of the relics according to the norms established after the Council of Trent was under the jurisdiction of the local church, he therefore gathered all the favourable evidence he could find in order to build up a sound case. In particular, he collected all the testimonies of miraculous events connected to the finds - such as the scent of the Turpiana relics, the lights coming from the Sacromonte, and the protection of the entire city from the Plague in 1578. He even got architects to examine the ruins of the Turpiana Tower in order to prove that it pre-dated the Islamic conquest. ${ }^{16} \mathrm{He}$ had the lead sheets, the ashes, bones and receptacles in which they were found evaluated by experts - goldsmiths, silversmiths, engravers, blacksmiths, plumbers, charcoal burners, potters, and lime and soap makers - who all confirmed the antiquity and authenticity of the finds. ${ }^{17}$

However, the Nunciature and the Roman Church were unconvinced. Although they did not interfere with the authentication of the relics, in 1596 the Pope ordered the Archbishop not to discuss the books any more as the Pontiff alone was responsible for their judgement. Pedro de Castro did not follow this order, though. In fact, he went a stage further and contacted all the Orientalists and Arabic interpreters available in Spain (including Moroccan members of Muley Xeque's entourage) and did so at his own expense. Later on, he even contacted renowned scholars in Europe. ${ }^{18}$ Some of them were actually persuaded to move to Granada in order to translate and evaluate the parchment and Lead Books. Subsequently, many more transcriptions, copies, translations and reports were produced by these scholars, although the ones who first worked on the task (and did so more extensively) were actually the same people who translated the

16 The tower was attributed to Jews by the architect Ambrosio de Vico (c. 1555-1623), which linked it to the theory postulated by Pedro Guerra de Lorca (d. 1597) and Pedro Velarde de Ribera about an ancient Spain inhabited by one or more of the ten lost tribes of Israel. Luis de la Cueva, Francisco Bermúdez de Pedraza (1576-1655) and Justino Antolínez de Burgos supported the idea of the oldest populations on the Iberian Peninsula being of Phoenician origin and thus a similar origin for the Turpiana Tower. All of them affirmed that this first population must have been Arabic-speaking, regardless of its origin. See García-Arenal 2006b, 572-577; Harris 2007, 55-87; García-Arenal/Rodríguez Mediano 2013, 219-224; Urquízar-Herrera 2017, 172-179.

17 Harries 2019, 220-221.

18 See the correspondence between Pedro de Castro and the Dutch Orientalist Thomas Erpenius, for example; García-Arenal/Rodríguez Mediano 2013, 245. 
Turpiana parchment: Alonso del Castillo and Miguel de Luna. This search for skilled linguists is most likely to have been motivated by the need for the ideal translation: one accurate enough to be accepted by all the parties involved (the population, monarchy and papacy), but doctored enough to convey a 'proper' Christian message.

Meanwhile, the commission that had to evaluate the relics established their authenticity in April 1600, and in 1609 Sacromonte Abbey was founded by Pedro de Castro over the caves. At this point, everybody wanted to have the books: King Philip III wanted them in Madrid, the various popes that came in succession wanted them in Rome, but the Archbishop managed to keep them, and even after his death in 1623 the books remained in the Archive of the Four Keys in Sacromonte Abbey. The King only managed to obtain the books in 1632, despite the monks' refusal to hand over their key. ${ }^{19}$ Philip III did not have them for long, though, as he was obliged to send them to Rome in 1643 when Pope Urban VIII threatened him with excommunication if he failed to do so. Once in the Vatican, they were studied and assessed by a committee established in 1645, composed of cardinals and six clergymen - expert Orientalists - who were tasked with the translation of the books. They were Antonio dell'Aquila, Bartolomeo de Pettorano, Ludovico Marracci, Giambattista Giattini, Athanasius Kircher and Filippo Guadagnoli (who died before completing the translation) ${ }^{20}$ The committee finished its translation in 1665 and a list of Islamic terms used in the books was included in the report. Due to several diplomatic attempts organised by the Abbey with the King's support, the final decision was delayed until 1682, almost a century after the discovery of the Lead Books, when Pope Innocent XI declared the finds to be fake and heretical.

This could have been the end of the story, but it was not. The relics and the books - especially the passage in favour of the Immaculate Conception - were so widely venerated in Granada and, indeed, the whole of Spain that the sentence was not accepted: important people - among them King Charles II and his mother - wrote to the Pope asking him to reconsider his decision. Printed books, pamphlets and manuscripts defending the Lead Books were produced and circulated well into the eighteenth century. ${ }^{21}$ The last attempt trying to rehabilitate the

19 The Chancery officials were forced to smash the lock; Harris 2007, 45.

20 For more information concerning this committee and the people that were part of it, see García-Arenal/Rodríguez Mediano 2013, 297-305; Martínez Medina 2015, 185-190.

21 To quote a few examples, Información para la historia del Sacromonte by Adán Centurión y Córdoba, Marquis of Estepa, the first part published in Granada in 1632 and later put on the Index of Prohibited Books, then re-edited in 1706 in Lyon under the title of Relación breve de las reliquias que se hallaron en la ciudad de Granada; Vindicias cathólicas granatenses by Diego de 
books was staged in 1754 when Juan de Flores y Oddouz started digging in the area of the Alcazaba under the supervision of a commission which included such names as Cristóbal de Medina Conde, Juan Velásquez de Echeverría and Luis Francisco de Viana y Bustos (canon of the Cathedral of Malaga, and canon and the Abbot of Sacromonte respectively). Flores y Oddouz discovered several inscriptions on marble and lead tablets in writing similar to the 'Solomonic' and Spanish-Baetic characters found on the Sacromonte leaves. These new finds 'proved' that everything was true: the identification of modern Granada as the ancient city of Ilíberis, its evangelisation by St James, the dogma of the Immaculate Conception and even the authenticity of the Lead Books and the treasures of the Turpiana Tower. The excavations continued until 1763 when they stopped due to a lack of financial sponsors. As a consequence of the negative reports produced by Spanish and foreigner specialists, Charles III ordered the evaluation of the finds by royal decree in 1774 . This time, the forgeries were quickly exposed, and the authors were punished in 1777. The artefacts themselves, fake and authentic alike, were all destroyed. The involvement of the Sacromonte in this matter marked its inevitable decline along with the Lead Books' cause, as later authors would rarely defend their authenticity. ${ }^{22}$ Despite this, people kept on supporting and venerating the fictitious Christian history of the city, along with the figure of St Caecilius and his relics.

\section{The reception}

As Mark Jones states: 'Faking is itself an index of the value of the objects faked'. ${ }^{23}$ The Sacromonte forgeries are not copies of a specific object, however, but original artefacts that their creators wanted to be perceived as something they were not: ancient and holy relics and books transmitting a reliable message. Borrowing the

\footnotetext{
la Serna Cantoral, published in Lyon in 1706 by royal commission; Guerras catolicas granatenses written in 1730 by Vincente Pastor de los Cobos; Mystico Ramillete published in 1741 by Diego Nicolás de Heredia y Barnuevo; Historia authéntica del hecho de los dos descubrimientos de Torre Turpiana y Monte santo de Granada by Luis Francisco de Viana y Bustos and José Juan de Laboraría, commissioned by Ferdinand VI in 1756, but never published due to the new discoveries of the Alcazaba. See Barrios Aguilera 2011, 239-358; García-Arenal/Rodríguez Mediano 2013, 32.

22 These authors were strictly connected to the Sacromonte institution, however, one example being Zótico Royo Campos, canon of the Abbey from 1925 and abbot from 1955 up to his death in 1971.

23 Jones 1992, 9.
} 
words of Elizabeth Drayson, 'fakes represent what the recipients most want', ${ }^{24}$ meaning that in order to understand the impact that forgeries have on a community, the forgers' intentions are less important than how their forgeries are interpreted by the people who see or use them. This can be clearly seen in the matter of the Sacromonte inventions, since they have been interpreted in many ways and used to support completely different causes. In this sense, it is important to remember that every translation and interpretation is biased, as it is used to strengthen the position of the group that is supporting it. ${ }^{25}$

Outside Spain, the relics were quickly identified as fakes, with scholars pointing out many specific problems, inconsistencies and outright impossibilities that clearly framed the finds as recent fabrications. In Spain, too, scholars versed in the Oriental languages considered the books fakes, with the important exception of Bernardo de Aldrete and, of course, the two translators Alonso del Castillo and Miguel de Luna. The scholars agreed that the parchment and books were made by Moriscos and that Christian themes were used to mystify the heretic Islamic message that the books conveyed. The sole dissonant voice belonged to Ignacio de las Casas, the most ferocious opponent of the Lead Books, who instead identified concepts from the heresies of Arianism and Nestorianism, thus believing the forgeries were of an Oriental origin. Others, such as Juan Bautista Hersonita, Marco Dobelio and Diego de Urrea, affected support for the authenticity of the objects or avoided giving their opinion while under the hostile influence of the supporters of the finds.

The Pope and the clergymen in Rome also opposed the discoveries. Their rejection was most likely motivated by political and doctrinal reasons, such as maintaining the status quo of a Church led by the Roman community. This meant that both the hysteria of the population and the claims of the laminarios - the name given to the literate, more or less renowned, who stood in defence of the finds - fell on deaf ears and failed to really influence the papacy. In Spain, however, the consensus in favour of the finds' authenticity was almost universal, with the exception of the aforementioned scholars and their few followers.

24 Drayson 2013, 111.

25 Hagerty defines the concept of 'traducción interesada' (biased translation) as 'traducción interlingüística en el que el traductor traduce consciente y tendenciosamente como concepto preciso un concepto no expresado con precisión en el texto original' (interlinguistic translation in which the translator consciously and tendentiously translates a concept that is not expressed as a precise one in the original text). He divides the translators of the Lead Books into two large groups: those who a priori condemned the books as forgeries and those who a priori accepted them as genuine; Hagerty 1991, 1179-1181. 
The Morisco community was obviously one of the groups that supported the finds. The Arabic origins of St Caecilus and St Ctesiphon and the Arabic language used for the texts were essential for the arguments about the acceptance and assimilation of Moriscos' cultural values in the new social context of Catholic Spain. This not only found the passionate support of the Nasrid noble families, but also that of the Marranos, who joined the cause in the hope of being included in the process of acknowledging minorities. ${ }^{26}$ Unfortunately, the exacerbation of the measures against the Moriscos and their final expulsion limited the diffusion and influence of this view.

With time, a different reading of the books started to gain favour among the Moriscos, especially those who had to leave Spain: the true message was not that some Arabs (and their Arabic language) were among the first Christian saints, thus redeeming the Moriscos and their culture, but rather that Islam was the one true religion and that the mysterious content in one of the Lead Books (The Truth of the Gospel, better known as the Mute Book) ${ }^{27}$ would somehow lead the whole world to embrace it. The main supporter of this view was Ahmad ibn Qāsim alHajarī, also known by the Spanish name of Diego Bejarano. In his book Kitāb Nāṣir al-dīn (1637), he says that he translated the Turpiana parchment for Pedro de Castro (possibly around 1598), who then paid him to revise his translation because it was too Islamic. Al-Hajari commented that the Spanish translations were full of errors, lies and false Christian interpretations. The existence of commented Arabic transcriptions shows that the texts were also circulating in an Islamic environment and highlights their ambivalence, which was probably intentional. ${ }^{28}$ This interpretation came to leverage another legendary text, the Gospel of Barnabas. $^{29}$

Just as the Roman Church had political reasons to be against the Sacromonte artefacts, the Spanish Church and in particular the clergy of Granada had political reasons to be in favour of them: they gave Christian roots to Granada, which

26 See the support offered by Jeronimo Román de la Higuera in his letters to Pedro de Castro, for example.

27 The Mute Book is a particularly puzzling artefact: it consists of 16 leaves filled with symbols and letters. So far, it has been impossible to decipher it.

28 This ambivalence is clearly shown by Roisse in his analysis of the content of the Lead Book, The History of the Seal of Solomon; Roisse 2006.

29 This text was probably produced in the Morisco circles in Istanbul around 1600. For further readings about the content and circulation of the Gospel of Barnabas, the involvement of Muhammad b. Abī al-'Asī and his possible identification with Alonso de Luna, the connection of this text with the Lead Books and the Morisco communities, see Pons 2006; Roisse 2006; Wiegers 2006; Drayson 2013, 176-182; García-Arenal/Rodríguez Mediano 2013, 148-153. 
helped to counterbalance and possibly forget the previous seven centuries of Islamic rule, they gave Granada leverage to claim religious primacy over other Spanish cities, and they sparked and inflamed renewed religious fervour in the population. They also lent credit to the doctrine of the Immaculate Conception - an extremely debated topic at the time - which was very close to the hearts of both the Spanish Church and the monarchy. ${ }^{30}$ Archbishop Pedro de Castro was an active supporter of this doctrine, so much so that the quote 'a Maria no le tocó el pecado original' (Mary was untouched by original sin), translated from the Lead Book called Fundamentals of the Faith, became his and the Sacromonte's motto. ${ }^{31}$

Besides the passion that Philip II had for relics, the Crown had its own political interest in seeing the finds legitimised. The prophecy found in the text of the Lead Book called Book of the History of the Truth of the Gospel caught Philip's eye because a dialogue between the Virgin and St John mentions the figure of a man favoured by God, a man who will help to spread the Gospel, a king of the Arab kings who is not himself an Arab and who will be feared by everyone in the West. ${ }^{32}$ The Spanish Crown read this as a clear reference to the Christian monarchs who reconquered Spain from the Muslims, and both Philip II and Philip III fancied themselves to be kings favoured by God. To support this reading of the Lead Books and the claim to their authenticity, both the Spanish Church and the Crown exerted considerable pressure on the academic scene at that time.

Actively supporting this Christian reading of the Lead Books were the laminarios such as the aforementioned Pedro Guerra de Lorca, who were instrumental in manipulating the people of Granada and later of all Spain. Their main strategy was to spread the theories and evidence supporting the authenticity of the discoveries; essays, pamphlets, copies and translations were printed and circulated by them for this reason. These texts were full of fantastic theories that were often unacceptable to the scholarly community, covering such things as the antiquity of the Spanish language, from which Latin was supposed to be derived, or the Phoenician origin of the Arabs in the peninsula, both of which were theories which rested on questionable sources such as invented chronicles and forged

30 The Immaculate Conception was only declared dogma in 1854 (by Pius IX). In Spain, during the sixteenth and seventeenth century, universities pronounced vows to defend the doctrine at any cost. Temples and columns were erected to commemorate the triumph of the Immaculate, and the schools of plastic arts in Seville and Granada created the iconography to express the concept that was absorbed and accepted in all European Christian art, thanks to the works by Alonzo Cano and Bartolomé Esteban Murillo, for example. Martinez Medina 2015, 311-318.

31 He had the quote inscribed on the foundation stone of Sacromonte Abbey and his personal seal together with the Seal of Solomon, also taken from the Lead Books.

32 Martinez Medina 2015, 135. 
documents. It is notable they chose to use printing, thus multiplying the number of copies and the diffusion of their works. The actual scholars studying the matter were not as direct and outspoken as the laminarios, and whenever they attempted to voice their doubts and criticism, mostly by exchanging private correspondence or by circulating manuscripts in a small circle of academics, they suffered opposition and discredit at the hands of the laminarios, who often resorted to attacking the person by questioning their competence and motives rather than engaging with the argument itself. ${ }^{33}$ The case of Ignacio de las Casas is exemplary in terms of the intensity and persistency of the attacks: he was described, even centuries after his death, as an ignorant, lying Morisco who was jealous of the official translators, and was even accused of being a crypto-Muslim..$^{34}$ Looking at the laminarios, we can easily see a coordinated public effort to push and defend their opinion in favour of the Sacromonte artefacts. It is unclear whether the scholars adopted a comparable approach in order to present and support their critical views or if they mostly worked alone and privately. A few manuscripts presenting a collection of such scholarly critiques are known to exist, but without further research it is unclear whether these books were produced by the scholars as a way to circulate their results or they were a private collection produced by certain laminarios to methodically organise their defence of the artefacts (Fig. 5). ${ }^{35}$

33 They were despised by their opponents both as persons and as scholars. For example, Marco Dobelio described them as 'personas ricas y poderosas que no admiten razón ninguna, sino el propio capricho' ('rich and powerful people who admit no reason but their own whim'). Rodríguez Mediano/García-Arenal 2006, 328.

34 The resentment towards this scholar was still felt in 1759 when Viana and Laboraría wrote a completely forged biography of him in their work Historia authéntica del hecho de los dos descubrimientos de Torre Turpiana y Monte santo de Granada.

35 I am referring in particular to three multiple-text manuscripts: Madrid, Biblioteca Nacional de España MS 7187, London, British Library Add. 57490 and Valencia, Biblioteca Historica de la Universidad de Valencia MS 376. The Madrid manuscript contains the following texts: 1) Discurso de Gonzalo de Valcárcel o Valcázar; 2) Parecer del obispo de Segorbe Juan Bautista Pérez; 3) Discurso atribuido a D. Francisco Aguilar Terrones del Caño; 4) Discurso de D. García de Silva; 5) Carta de Benito Arias Montano al arzobispo de Granada, de 3 de mayo de 1595; 6) Carta del obispo de Segorbe, Juan Bautista Pérez, a un corresponsal anónimo, de 8 de junio de 1595; 7) Carta del P. Ignacio de Las Casas S.J., al cardenal Belarmino; 8) Carta del P. Las Casas al cardenal Baronio; 9) Informe del P. Las Casas al papa Paulo V sobre lo hallado en Granada (1607); 10) Parecer de Pedro de Valencia al cardenal D. Bernardo de Rojas y Sandoval, Inquisidor. In the margins, there are annotations written in reply to the critics of the main texts. They are most likely in the hand of Adán Centurión, Marquis of Estepa, and they are probably the preparatory work for the second part of his Información para la historia del Sacromonte. The London manuscript is a direct copy of the Madrid exemplar, with the difference that the annotations are grouped at the end of every part. The Valencia manuscript contains the same texts of the 


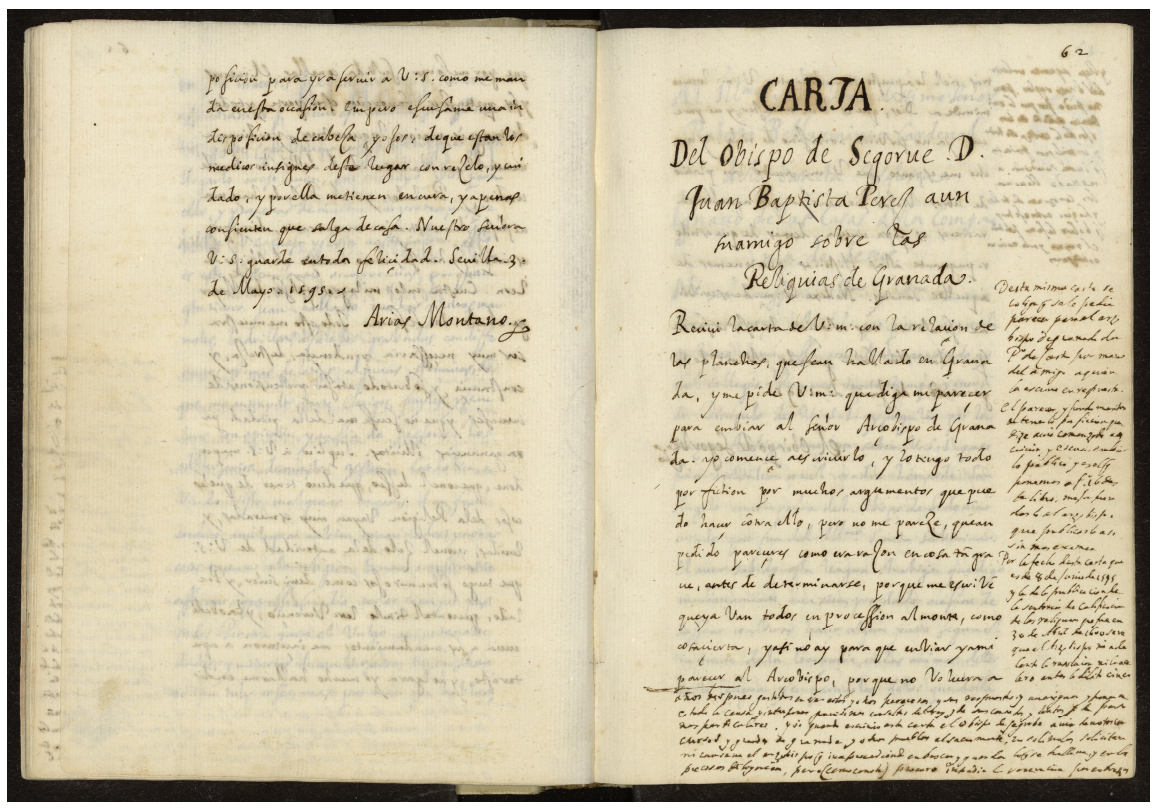

Fig. 5: End of the copied letter by Arias Montano to the Archbishop of Granada and beginning of the copied letter by Juan Bautista Pérez to an anonymous correspondent. Some annotations can be seen in the margins that were probably made by Adán Centurión, Marquis of Estepa. Madrid, BNE 7187, fols 61v-62r; (C Reproduced by kind permission of the Biblioteca Nacional de España.

Another way of winning favour for the laminarios' and Sacromonte cause was to bribe conniving scholars, which proved to be particularly effective with foreign Orientalists such as Juan Bautista Hersonita, the Archbishop of Mount Lebanon, who even agreed to move to Spain to assess the finds after being contacted by Pedro de Castro and his agents. Alternatively, as with Marco Dobelio, a Kurdish academic residing in Italy, those who could not be bribed were blackmailed, leveraging the economic problems of foreign translators who, once in Spain, had no resources or contacts to count on. ${ }^{36}$

previous books with the exception of the last one (Parecer de Pedro de Valencia) and of the annotations. Benitez Sánchez-Blanco 2006a, 143-144.

36 Their stories were reported by Luis Tribaldo de Toledo, bearing the charge of Cronista Mayor de las Indias and opponent to the discoveries, in an exchange of letters with the Marquis of Estepa in 1633 concerning the translation of the Lead Books published by the latter. See Harvey/Wiegers 2011. 
When no other means seemed to work, the scholars were even reported to the Inquisition, as in 1618 when the papers and drafts of Pedro de Valencia, Francisco de Gurmendi and other members of their circle in Madrid were confiscated. The official reason was the application of the breve by Clemens VIII from 1596, prohibiting discussion about the finds and advocating their assessment to the papacy alone. A more probable reason was the intention to block the printing of what was supposed to be an extremely critical text by renowned scholars who were totally independent from the control of the Archbishop of Granada. The members of this circle, although crippled by the Inquisition's acts and control, continued to express their opposition to the Sacromonte finds at court. Unfortunately, the majority of the papers produced in connection with this circle have since been lost, possibly dispersed or destroyed soon after the deaths of its members.

In this exceedingly hostile environment, it is not surprising that several scholars tried not to get involved in the matter in the first place, possibly for fear of retaliation or because it already looked like a lost cause. In a letter to Arias Montano, Juan Bautista Pérez, the bishop of Segorbe, for example, wrote that it would have been useless to send his report to the General Inquisitor, who had commissioned it in 1595 , since Pedro de Castro would not listen to any unfavourable opinion due to his own involvement.

\section{The scholars' methodology}

The scholars involved in the evaluation of the Sacromonte finds employed various methods to reach their conclusions. But while the relics were tested by experts and artisans of various professions for the purpose of their evaluation, ${ }^{37}$ only a few scholars had access to the written artefacts, with everyone else having to work on copies, transcriptions or mere translations (Fig. 6).

37 Harris 2019, 220-221. 


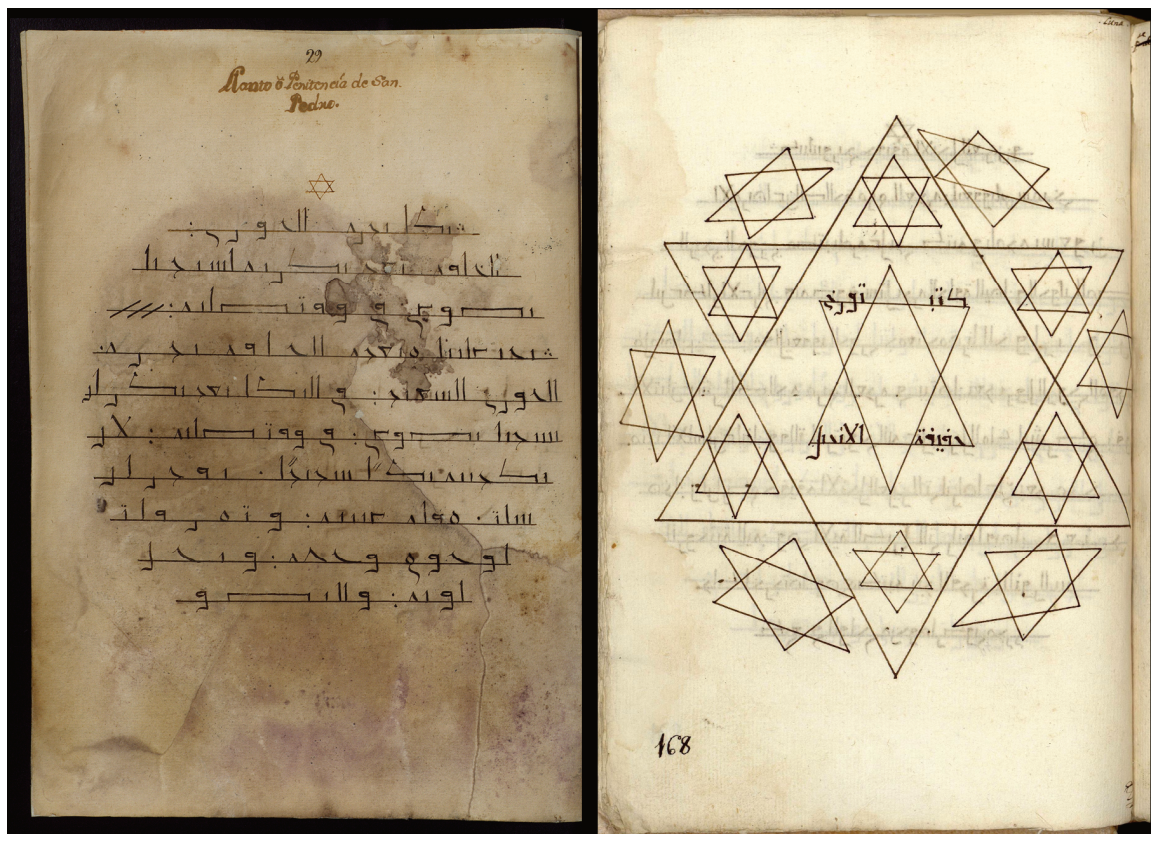

Fig. 6: On the left, a copy of the beginning of the Lead Book entitled Lament of Peter; Granada, ARCHGR 097COSAC, Caja 2432.6, fol. 29r; @ Reproduced by kind permission of the Archivo de la Real Chancillería de Granada. On the right, a copy of the beginning of the Lead Book On the History of the Certification of the Gospel; Archivo Abadía del Sacro Monte Granada, fol. 168r; (c) Reproduced by kind permission of the Archivo Abadía del Sacro Monte de Granada.

This lack of access to the originals prompted a host of complaints, as it forced the scholars to rely on secondary sources and made it virtually impossible to consider an artefact's materiality. This restriction was hardly a coincidence, as most observations based on the examination of the physical properties of the written artefacts seemed to quickly disprove their authenticity. For example, Pedro de Valencia highlighted how the state of the Lead Books' conservation was too good for an artefact that had supposedly been buried for centuries, Gonzalo de Valcárcel commented on the many methods and substances known to give metal an ancient look, such as acids, and Arias Montano found that both the parchment and the inks used were not ancient, but merely old and poorly preserved. He also noticed that the writing implement employed was a relatively modern quill (introduced in Europe less than four centuries earlier) rather than the reed pen used by Greeks and Romans. Access to the originals also allowed him and Marco Dobelio to spot parallels between the Lead Books and a tradition of talismans commonly produced 
in al-Andalus, as they both sported engravings of very similar symbols, shapes and layouts (Fig. 7). ${ }^{38}$ The dimensions of the Lead Books' leaves, however, are obviously bigger than those of the talismans since the former had to contain more text.

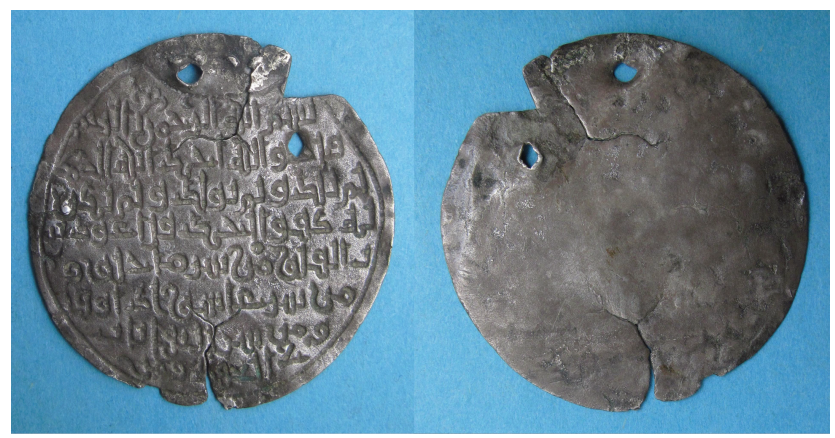

Fig. 7a: A circular lead amulet with part of Surah 112, $40 \mathrm{~mm}$ in diameter, possibly tenth century; Madrid, Tonegawa collection; images in Gaspariño 2010, TV6-0-3.

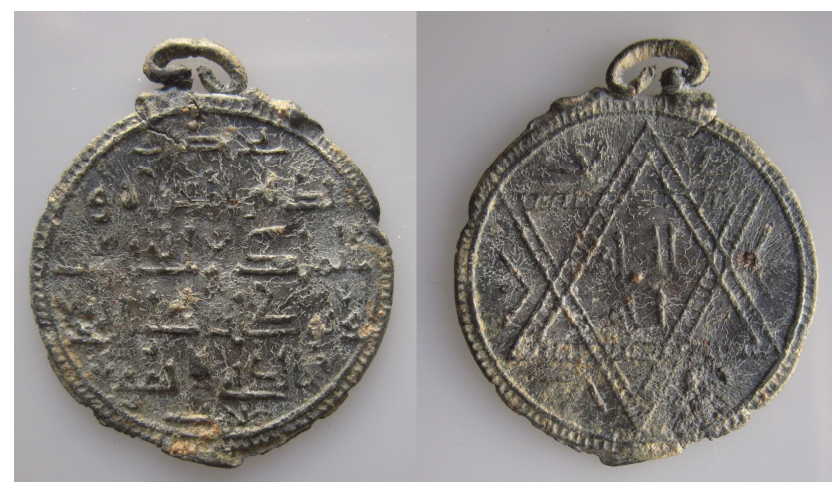

Fig. 7b: A circular lead amulet with an inscribed seal of Solomon, $25 \mathrm{~mm}$ in diameter, possibly tenth century; Madrid, Tonegawa collection; images in Gaspariño 2010, TV6-0-3; @ Figs 7a and $7 \mathrm{~b}$ : Reproduced by kind permission of Sebastian Gaspariño and the Tonegawa collection.

38 Regarding the description, fabrication and use of talismans and amulets in al-Andalus, also see Labarta 1982-1983; Martínez Enamorado 2002-2003, Gozalbes Cavioto 2005; Ibrahim 2006; Sánchez Gallego/Espinar Moreno 2017; Krasner Balbale 2019; and the web page Gaspariño 2010 (consulted online on 20 December 2019). 

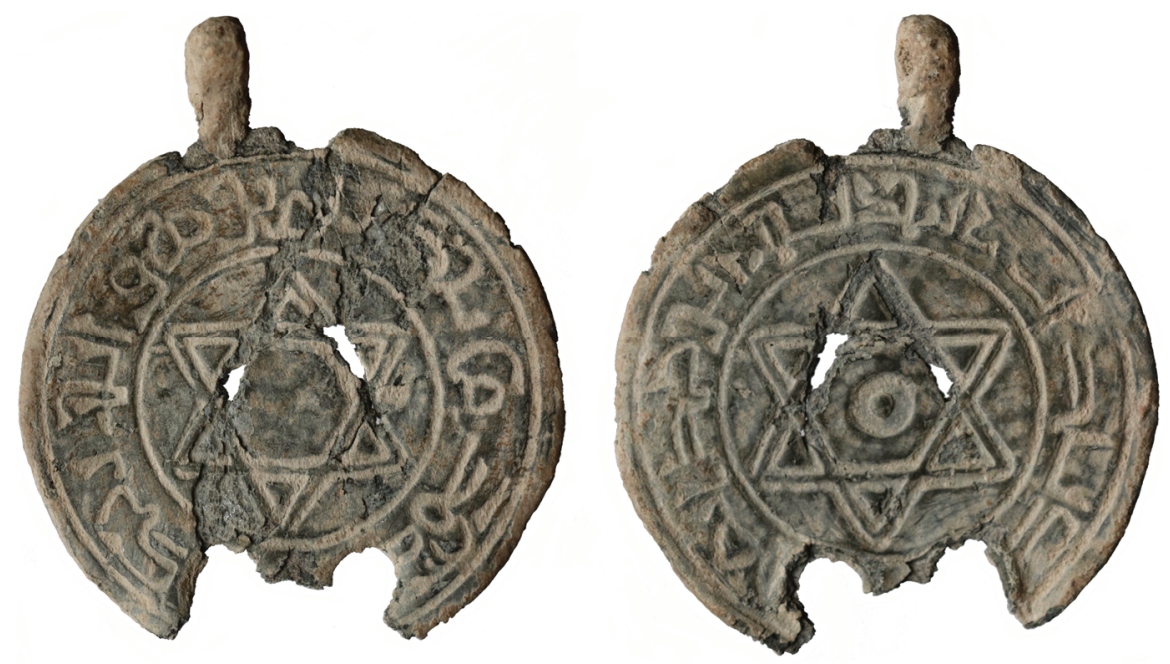

Fig. 7c: A circular lead amulet containing the seal of Solomon, $32 \mathrm{~mm}$ in diameter, possibly thirteen century or later; private collection; image in Gaspariño 2017, 80; @ Reproduced by kind permission of Sebastian Gaspariño.

Another feature shared by the Lead Books and the majority of the talismans produced in al-Andalus is the use of lead for the writing support. This metal was of great significance at the time and was probably part of the stagecraft designed to bestow power to the fake artefacts. On the one hand, the common folk of alAndalus were used to associating mystical value to lead as it was the material of choice for many charms and talismans; being soft, the metal was easy to inscribe even with crude tools, while the presence of lead mines in the area made it both cheap and easy to obtain..$^{39}$ These talismans were popular among Jews and Christians alike, leading to a melting pot of symbols and icons - again, as we find

39 There are deposits of lead in Linares and La Carolina (north of Jaén), in Sierra Morena (north of Cordoba) and in Sierra Almagera and Sierra de Gádor (in Almería). Lead was also mined in Elvira and Berja. Silver was mined at Guadalcanal in the Sierra Morena, in Elvira and Jaén. Since lead is a by-product of silver extraction, these places are another possible source of the less expensive metal; Imamuddin 1981, 101-102; <https://www.juntadeandalucia.es/institutode estadisticaycartografia/atlashistoriaecon/atlas_cap_25.html\#> (consulted online on 20 December 2019). Martínez Enamorado observes that the talismans combined magical and cabalistic formulas with religious content (frequently in the form of Qur'anic quotes), which are characteristics of popular religious practices. The lack of formal repetitions in the selected passages and the variety of forms (circular vs rectangular) and layouts suggest rural production in numerous places; Martínez Enamorado 2002-2003, 115-127. 
in the Lead Books. Using talismans was common among the more educated segments of the population as well, and even among the clergy: Dobelio reported with disgust how Pedro de Castro had them, too. ${ }^{40}$ They were so popular, in fact, that in 1526 the Council of the Royal Chapel in Granada issued a prohibition to prevent the Moriscos from wearing metallic charms bearing writing, hands or other symbols - referring most likely to the hand of Fatima or Hamza and the seal of Solomon. This ban would go on to become the main focus of many Inquisition cases. ${ }^{41}$

On the other hand, scholars connected the use of lead to its value in alchemy and astrology, especially thanks to the many repetitions of the six- (or sometimes five-)pronged star motif on the Lead Books - a clear reference to Solomon's seal. ${ }^{42}$ This connection summoned up images and meanings found in the aforementioned Islamic and Hebrew talismans, but also in magical and alchemical manuscripts such as the Clavicula Salomonis (the Key of Solomon) or the Picatrix, translated in Spain in 1256 for Alfonso X the Wise, which links lead to the planet Saturn. ${ }^{43}$ In name, layout and conception the previously mentioned Mute book quite closely resembles an old Latin alchemical treatise made of images called the Mutus liber. ${ }^{44}$

Although it is unclear whether the actors involved in the Sacromonte events were aware of ancient magical practices from the Mediterranean area (which is quite unlikely), some of their ideas may have trickled down through history: the use of lead as a conduit for magical energy and signifiers has roots in Greek and Latin culture where it was employed to enact curses, often by encasing a paper or parchment text within lead sheets or boxes (just like the Turpiana box and the Sacromonte books). ${ }^{45}$ Finally, the discovery of a hermetic metallic box containing

40 García-Arenal/Rodríguez Mediano 2010, 275.

41 Labarta 1982-1983, 185-188; Drayson 2013, 32-37.

42 'Solomon was a great magician, according to Muslim belief; his ring plays a great part in Talmudic legends and Arabian tales. [...] The talisman, still known as Solomon's seal and worn by Muslims and Jews alike, represents a six-pointed star'; J. Ruska, B. Carra de Vaux, and C. E. Bosworth, 'Tilsam', in: Encyclopaedia of Islam, Second Edition, edited by P. Bearman, T. Bianquis, C. E. Bosworth, E. van Donzel, and W. P. Heinrichs. Consulted online on 20 September 2019; <http://dx.doi.org/10.1163/1573-3912_islam_SIM_7553>.

43 Drayson 2013, 23-37.

44 The first printed edition appeared in la Rochelle in 1677; Drayson 2013, 28.

45 It was believed that the magical protection or curse it contained would cease to be effective once the written text was disclosed; Curbera 2015, 105-107. On Greek and Latin curse tablets found in Spain, see Curbera et al. 1999. 
a prophecy is a common topos in many Arabic stories and lead was often used by Moriscos for divination. ${ }^{46}$

Despite it having access to the physical artefacts, the committee in Rome chose to focus on the historical, theological and linguistic analysis of the texts they contained. The same analyses were carried out by the Spanish scholars who studied the finds. The first and main issue was understanding the writing. The parchment containing the prophecy sported Arabic annotations in the margins of the text which are almost illegible because they mimic an extremely slanted cursive script. The prophecy and its comment use Latin and Greek characters to write Arabic words, all organised within two grid tables. As a result, the text can be interpreted in different ways depending on the order used to read the various sections of the tables.

Coming to the Lead Books, the identification of the phonetic value of the characters was a problem in itself. In Arabic script, several letters may share the same basic shape (rasm) and are only distinguished with the help of diacritical signs (dots) above or below the character. Unfortunately, the Sacromonte books were written in the so-called Solomonic script, which lacks both diacritics and the signs for short vowels. As a result, every word can be read in several ways, leading to starkly divergent interpretations. It is possible that this script was chosen as one of the ways to make the books look more antique, as its very angular characters (possibly due to the technique used to scratch the writing on the lead) reminded the viewer of various historical and mystical scripts such as the Early Abbasid styles and the New Style of early Qur'ans (inaccurately referred to as Kufic), or the epigraphic script found in al-Andalus talismans, or even the one used in the Clavicula Salomonis and other books on astronomy and necromancy. Moreover, the absence of diacritic signs and short vowels was typical of the most ancient forms of Arabic.

It is interesting to observe how these elements were adopted by different scholars to support opposing views: according to intellectuals such as Ahmad ibn Qāsim al-Hajarī and other laminarios, they support the antiquity of the artefacts since the scripts used in modern occult treatises and talismans are derived from what was employed in the Lead Books, thus inheriting the observed common traits. According to academics such as Juan Bautista Perez, the opposite was true; he identified occult texts as the original inspiration for the production of the al-

46 The knowledge of witchcraft and necromancy that the Moriscos of al-Andalus possessed, in particular those from Granada, was already a literary topos in the sixteenth century. They were particularly renowned for making (and wearing) powerful talismans and charms. See Drayson 2013, 23-37. 
leged Sacromonte relics. Modern experts like Koningsveld seem to agree with the latter point of view, highlighting inconsistencies and errors in the evaluations. Al-Hajarī, for example, stated that the Solomonic characters were ancient and came from the East, while in reality some letters bear a clear resemblance to Maghribi characters and therefore came from the West, if anything. ${ }^{47}$

Arias Montano, who analysed the palaeographical characteristics of the Latin texts on the parchment and the unbound lead sheets labelling the relics, was one of a small number of scholars who observed that the characters did not match those of the period. Once again, however, the use of pseudo-antique characters, such as Spanish-Baetic ones, was meant to root the finds in local history, suggesting there was a similarity with the scripts found in the inscriptions on ancient Iberian coins. ${ }^{48}$

The languages used in the finds were also studied extensively. The Spanish passages were a problem, as that language was not supposed to exist at the time the relics were thought to have originated. Some laminarios actually theorised that Spanish was older than Latin in a bid to explain its use in the parchment. A quaint position was that of Bernardo de Aldrete, who, being both a supporter of the relics' authenticity and a knowledgeable linguist, proved the laminarios wrong by demonstrating how Spanish had descended from Latin, only to then explain its use in the parchment as God's gift to the Apostles of being able to speak all languages: being omniscient, God would have known the time of the find, and therefore the parchment was written in a language the readers could understand, even though it was not yet in use at the time the relics were produced. Another issue was the Arabic language, which was forbidden by the Spanish monarchy as an expression of Islam. In this case, the laminarios tried to show how Arabic was, in fact, a Christian language and that the Arabic alphabet was introduced in Spain by the Phoenicians. As we have already seen above, this was a theme particularly dear to the Morisco community.

The other languages present in the prophecy text were problematic, too, as Arias Montano pointed out: the vocabulary and structure of the parchment - supposedly a translation from Hebrew into Greek, then into Latin and finally into Spanish - did not coincide with the vocabulary and structure of any language used at the supposed time of production. Moreover, several scholars noticed how both Spanish and Latin terms were employed according to their

47 However, he recognised that the hand or hands that wrote the Lead Books were experienced in writing in Arabic script, although it was most likely to have been a modern one. See Koningsveld/Wiegers 2003, 346-349.

48 Harris 2019, 218. 
contemporary usage rather than the forms that would have been historically accurate. Take, for example, the word divos, typical of late medieval Latin, which was used in the lead sheets to indicate saints, or the concepts and words moros, mozarabe and aljamía, which only came into use after the Islamic conquest. ${ }^{49}$ The Arabic wording had the same problem and even sported characteristics typical of the dialect spoken in Granada and the Maghreb at the time of the discovery.

The literary style used was also inconsistent, further eroding the credibility of the texts as a unique and original historical work. Francisco de Gurmendi noted how the linguistic register clearly differed between the refined parts, copies or adaptation of Qur'anic excerpts and the rough and dialectal ones, corresponding to the new material inserted by the forgers. Marco Dobelio highlighted that this new material did not correspond to any ancient author in terms of its language and style, regardless of whether he was Arabic or Christian.

Beyond the language, the content was also extremely controversial: the ambiguity of the translations led to a message that could be understood as Catholic or Islamic, depending on the interpretation. Marco Dobelio observed the use of Islamic terms to express Christian concepts, a fact that was also detected by the scholars working in Rome. This discovery was of particular importance in evaluating the adherence of the texts to Christian doctrine and language and was used as an argument to declare the authors heretics..$^{50}$ This is only partially accurate, however. If these terms confirm the modern origin of the finds, they do not automatically characterise the texts as being Islamic since Mozarabs made use of terms with an Islamic tradition acquired from the Arabic language in order to express Christian concepts in their own texts. ${ }^{51}$ The same terms even appear in the catechism and glossaries by Pedro de Alcalá and other Christian authors, tools employed in the preaching and conversion of the Moros after the fall of Granada. ${ }^{52}$ The Mozarabs' books and the Christian glossaries were probably the linguistic models used by the forgers to produce the new parts of the texts in the Lead Books.

49 Benitez Sanchez-Blanco 2006a, 155-156.

50 Scholars in Rome, in particular, compared the language used in the forgeries with that of the Maronites, who monopolised the canonical Arabic versions of the Christian texts in the sixteenth and seventeenth century. The Maronites wanted to show that their orthodoxy had not been contaminated by long centuries of co-existence with followers of Islam, and thus purged their language of any shared terms. See García-Arenal 2009, 524.

51 Interestingly enough, both Alonso del Castillo and Miguel de Luna had access to such texts, as many of them were kept in El Escorial Library, which they went to between 1570 and 1594. López Tamarid consulted a Mozarab gospel in 1565 thanks to his work for the Inquisition.

52 García-Arenal 2009, 527. 
Putting aside the theological dispute extensively treated elsewhere, ${ }^{53}$ it is interesting to note how the scholars tried to focus on the logical and historical plausibility of the content. Arias Montano, Juan Bautista Perez and Gonzalo de Valcárcel asked themselves (and the laminarios) the following questions: Why were the books written in Arabic using characters that were so difficult to read if the passages they contained were meant to be preached to the reader's followers? If we assume that Arabic was spoken in Spain when the texts were originally written, why were the names of the people translated into Latin? And if we assume that Spanish was already spoken, as the parchment suggests, why were the Books written in Arabic in the first place?

Moreover, several historical incongruities are present in the texts: for instance, the name of the town used in the parchment, Granada, when it should have been Ilíberis, as attested in Roman inscriptions. ${ }^{54}$ The scholars also noticed that some theological concepts expressed in the Lead Books, such as the Trinity and the Holy Spirit, had only been conceived during the First Council of Nicaea (325 CE) and Constantinople (381 CE), thus making them alien to the apostles and Saint Mary, who could not possibly have conveyed them in their books. A similar argument was brought forth by Gonzalo de Valcárcel: how could the parchment refer to St John as a saint and evangelist if it dated back to a time when he was still alive and had not composed his Gospel yet? And how could the beginning of his Gospel, written in Greek, be present in the parchment (and have been translated into Latin and then Arabic) when it had not even been written? What's more, Nero did not persecute Christians before the tenth year of his reign, while the date reported on the Sacromonte lead sheets puts the martyrdom of St Caecilius in the second year of Nero's rule, corresponding to $58 \mathrm{CE}$.

In another example, Arias Montano pointed out that the early Christian authors always mentioned Jesus as the 'son of God' and never as the 'spirit of God', the latter being the expression used in the Lead Books. ${ }^{55}$ Concerning the prophecy in the parchment, he noticed that the prediction is clearly made in retrospect and that the method employed to encrypt the message is similar to the word plays used by alchemists and Paracelsians, albeit less refined. Marco Dobelio followed

53 Regarding the contributions dealing with the theological meaning of the Sacromonte finds and the dispute generated by them, see Martínez Medina 2015 and Benítez Sánchez-Blanco 2006b in particular.

54 Even the identification of modern Granada with Roman Ilíberis was a topic of debate (as it still is).

55 The same expression was used in a talisman written in Brillenbuchstaben and owned by a certain Juan Andres, who was judged by the inquisition of Cuenca in 1557. It was translated by Diego de Urrea. See Labarta 1982-1983, 187-188. 
a similar path by comparing the texts in the finds with Arabic manuscripts in his personal collections and, even more relevantly, with books belonging to individuals in the Morisco community in Pastrana that had been found and confiscated by the Inquisition after the Moriscos' expulsion. ${ }^{56} \mathrm{He}$ demonstrated that the histories of Jesus, Moses and Solomon in the Lead Books are very similar to those told in Islamic sources, ${ }^{57}$ that the type of writing and the seal of Solomon could be found in the Qișaș al-Anbiy $\bar{a}^{\prime}$ by al-Tha 'ālabī and Ibn Wathìma, and that various Qur'anic quotes can be found in the texts in the Lead Books - he even provided the exact passages from which they were copied. If the books pre-date the Islamic religion, how can they contain so many Islamic messages and quotes? This thorough analysis allowed Dobelio to contextualise the production of the books with the fatwa of the Mufti Abū al-'Abbās Aḥmad ibn Abī Jum'a alMaghrāwī, granting Muslims living in Spain the moral and religious right to pretend to be Christian while practising Islam in secret. In his opinion, the use of symbols and writing systems taken from alchemical and magical works reinforced the secrecy and elitism of the texts in the Lead Books, which had been conceived to spread the Islamic message within the Catholic community. ${ }^{58}$

One particularly acrobatic debate focused on the figures of Caecilius and Patricius and the exact time of their deaths. The parchment contains a prophecy written by one hand and signed by Caecilius, bishop of Granada, who is identified as the saint who evangelised the Iberian Peninsula in Roman times, followed by a note written by a second hand and signed by a certain Patricius narrating how he is hiding the parchment and the relics from the Moors because of Caecilius' imminent martyrdom. There are two problematic statements in this note. First of all, more than 600 years lie between the time when St Caecilius was possibly martyred by the Romans and the time when the Moors conquered the Iberian Penin-

56 The town of Pastrana in the province of Guadalajara in Castile-La Mancha hosted a large community of Moriscos from Granada (which made up around 30 per cent of the city's population at the beginning of the seventeenth century). They experienced the same situation of abuse and marginalisation seen in their home-town and the rest of Spain. The community fought for their rights, and the dukes of the city partially supported them, possibly because of their economic importance - it was thanks to them that the city became one of the most important textile centres in Spain; see García López 1995. Amongst other things, the confiscated books now lost included a Pentateuch, an Islamic religious text, vocabularies and texts about grammar, philosophy, geometry and medicine; García-Arenal/Rodríguez Mediano 2013, 279-291.

57 In particular, he pointed out the similarities between certain texts in the Lead Books and the Kitāb al-Anwār by al-Bakrī, a thirteenth-century book extremely popular among the members of the Morisco community; García-Arenal/Rodríguez Mediano 2013, 285-289.

58 García-Arenal/Rodríguez Mediano 2013, 289-291. 
sula. In reply to this, the laminarios said that the parchment was antique and written by St Caecilius, and that it had been found later by a person named Patricius, who decided to hide it from the Moors. The second problem was that in the parchment, Patricius mentioned Caecilius' martyrdom as a current event relating to someone he knew personally. The laminarios' reply to this was that Patricius was talking about a different person that he knew who happened to be called Caecilius and was also a bishop. Among other people, Arias Montano rebutted such explanations by pointing out that the parchment appeared to be recent and did not date back to the first century CE. To this the laminarios replied that the parchment was, indeed, recent as it had been written by an anonymous scribe who copied the original prophecy of St Caecilius, which was annotated later and hidden by Patricius. The later Sacromonte finds seem to clarify the matter, stating that both St Caecilius and Patricius died together around $58 \mathrm{CE}$ when Nero was emperor, simultaneously proving the antiquity of the parchment and its contents while invalidating all the laminarios' arguments in defence of it, which re-opened the question of the artefact's age.

All of this created a complex puzzle of timelines in the centuries-long discussion about the relics' authenticity, a puzzle made even more complex by the inherent ambiguity of the source materials' language. It is important to note how the production and (staged) discovery of the forgeries took place over the course of several years and possibly involved numerous individuals. This could explain some discrepancies and inconsistencies in the message found in the texts in the parchment and the lead artefacts, and even among the books themselves. Two different conclusions are possible here: either whoever produced the forgeries tried to use later artefacts to improve the impact of earlier ones in a chain of subsequent finds or someone within their group decided to pursue a different agenda, unbeknown to the others.

Finally, Pedro de Valencia and Gonzalo de Valcárcel have pointed out how the mode of the discoveries was particularly suspicious, and made a very plausible reconstruction of the events: the box filled with the parchment and the relics may have been placed in the ruins of the Turpiana Tower after it was taken down; the books and the lead leaves were put in old sepulchres, next to the remains of unknown people, and then treasure hunters were guided in the area. Some of the latest Lead Books were even found outside the caves, in deposits of soil taken from them that were already examined, possibly because the entrance of the caves was too well-guarded to plant the forgeries inside them. The finds were then read and translated by the Morisco author(s) of the artefacts, the only one(s) who could really understand and interpret them. 


\section{Conclusions}

The Sacromonte forgeries are a perfect example of fakes produced with the intention of manipulating and rewriting history in order to obtain social and economic benefits by blending the Christian and Morisco communities and their values. They were most likely made by members of the Morisco community to improve their status in the new Christian society and ultimately avoid their own expulsion. The fakes are relatively new objects made in such a way as to remind one of a mystical and mythical past, and their materiality is connected with the magical and talismanic traditions of Muslim, Jewish and even Christian culture. These elements were presented within the context of a complex theatrical display based on translations of non-existing manuscripts, misinterpretations of existing inscriptions, and medieval legends and traditions both known and forgotten - a fiction being spun following the rhythm of multiple staged discoveries.

The story told by the forgeries aimed at establishing a new historic past - the role of the Arabs in the evangelisation of the Iberian Peninsula - that would help to guide the current social change brought about by the conquest of al-Andalus in the desired direction, in this case the rehabilitation of the Morisco people and culture. This invented history was built upon pre-existing elements such as the town of Iliberis, Bishop Caecilius, the legend of the Seven Apostolic Men and the evangelisation of al-Andalus by St James. The new fiction included the presence of the Apostolic Men in Granada, the Arabic origin of two of these men and a Christian message blended with Islamic doctrine.

Although these goals may have been the ones pursued by the forgers, it is 'the audience that makes the fakes', as Elizabeth Drayson provocatively puts it. ${ }^{59}$

In fact, the discoveries did not benefit the Morisco community as much as they will have hoped - although none of the individuals directly involved in the forgeries was expelled - but their meaning was twisted by the Spanish Church (the intended audience) to establish a different invented history: the existence of a Christian community in Granada long before the Muslim conquest and the attempt to forget those seven centuries of occupation. The passages in the Lead Books referring to Islamic culture and religion were underplayed or explained in light of the Christian message. However, this interpretation could not be acknowledged universally or stand the test of time. The invented history proposed by Pedro de Castro and the Spanish Church could not take root beyond their local circle since the conditions needed for its success were not present in

59 Drayson 2013, 111. 
Rome. Moreover, the failed forgeries of the Alcazaba tarnished the reputation of Sacromonte Abbey in Spain, too.

What was the impact of these events on the academic world, then? And which role did scholars play in the matter? On the one hand, there is no doubt that the Sacromonte finds stimulated Spanish Orientalism and the historical debate in Spain in the sixteenth and seventeenth century. ${ }^{60}$ This stimulated academic researchers to adopt a more critical and analytical approach, promoting the use of multiple ancillary disciplines in order to provide clearer and sounder arguments in favour or against a given theory. On the other hand, it showed how the role and importance of scholars and their academic results were mainly social 'tools' in the arsenal of the involved powers: a stamp of quality providing increased authority and credibility when convenient, or just an opinion easily ignored and silenced when contrary to one's interests. This is why, despite the overwhelming evidence against the Sacromonte finds, scholars were unable to persuade the population and the authorities that the artefacts were fake.

What makes the Sacromonte matter quite unique is the length of the debate surrounding such crude forgeries - literally two hundred years of fervent activity followed by two more centuries of trailing arguments - and the stark difference between the intended effect and the actual outcome. The fact that the scholars' reputation was exploited without much regard for the validity of their research is not surprising, really - this has happened frequently throughout history and it still happens today. Maybe Benítez Sánchez-Blanco was right when, introducing his research on the Sacromonte forgeries, he said: 'If it was legitimate to evaluate the efforts made by the many people involved [in the Sacromonte matter] - the reader and I included - in terms of their productivity, it is likely that far better results would have been achieved if we had devoted ourselves to a different activity'. ${ }^{61}$

\section{Acknowledgements}

I would like to acknowledge the help I received from Don Juan Sánchez Ocaña, María Luisa García Valverde and Antonio López Carmona and thank them both for their support and their granting me access to the Archivo de la Abadía del Sacromonte. Many thanks to David Torres Ibáñez for the information he provided me with and for my access to the Archivo de la Real Chancillería. I would also like to thank Teresa Espejo Arias for her support and Cornelius

60 García-Arenal/Rodríguez Mediano 2013, 9-11, 308, 339-341.

61 'Si fuera legítimo valorar el esfuerzo empleado por tanta gente como la que ha estado implicada - incluyéndome a mí y al lector - con criterios de productividad, posiblemente se hubieran obtenido mejores resultados dedicándonos a otra actividad'; Benítez Sánchez-Blanco 2006a, 144. 
Berthold, Michael Kohs and Karl Schaefer for their suggestions on the topic of amulets and talismans. This work was carried out at the SFB 950 'Manuskriptkulturen in Asien, Afrika und Europa', funded by the German Research Foundation (Deutsche Forschungsgemeinschaft, DFG) within the scope of the work carried out at the Centre for the Study of Manuscript Cultures (CSMC) in Hamburg.

\section{References}

Álvares de Morales, Camilo (2002-2003), 'Los libros plúmbeos, las historias eclesiásticas y la Abadía del Sacromonte de Granada a la luz de estudios recientes', in Chronica Nova, 30 : 729-747.

Barrios Aguilera, Manuel (2011), La Invencíon de los Libros Plúmbeos: Fraude, Historia y Mito, Granada: Universidad de Granada.

Barrios Aguilera, Manuel and Mercedes García-Arenal (eds) (2006), Los Plomos del Sacromonte: Invención y Tesoro, Valencia: Universitat de València.

Benítez Sánchez-Blanco, Rafael (2006a), 'El discurso del Licenciado Gonzalo de Valcárcel sobre las reliquias del Sacromonte', in Barrios Aguilera/García-Arenal (eds), 173-200.

Benítez Sánchez-Blanco, Rafael (2006b), 'De Pablo a Saulo: Traducción, crítica y denuncia de los Libros Plúmbeos por el P. Ignacio de las Casas, S.J.', in Barrios Aguilera/García-Arenal (eds), 217-252.

Cabanelas, Darío (1969-1970), 'Arias Montano y los libros plúmbeos de Granada', in Miscelánea de estudios árabes y hebraicos. Sección Árabe-Islam, 18-19: 7-41.

Cabanelas, Darío (1991), El morisco granadino Alonso del Castillo, Granada: Patronato de la Alhambra y Generalife.

Curbera, Jaime (2015), 'From the magician's workshop: notes on the materiality of Greek curse tablets', in Dietrich Boschung and Jan N. Bremmer (eds), The Materiality of Magic, Paderborn: Wilhelm Fink, 97-122.

Curbera, Jaime, Marta Sierra Delage, and Isabel Velázquez (1999), 'A Bilingual Curse Tablet from Barchín del Hoyo (Cuenca, Spain)', in Zeitschrift für Papyrologie und Epigraphik, 125: 279-283.

Drayson, Elizabeth (2013), The Lead Books of Granada (Early Modern History: Society and Culture), Basingstoke: Palgrave Macmillan.

Ecker, Heather L. (2002), “'Arab stones”: Rodrigo Caro's translations of Arabic inscriptions in Seville (1634), Revisited', in Al-Qantara 23, 2: 347-401.

Ehlers, Benjamin (2006), 'Juan Bautista Pérez y los Plomos de Granada: el Humanismo español a finales del siglo XVl', in Barrios Aguilera/García-Arenal (eds), 252-269

Floristán, José M. (2014), 'Francisco de Gurmendi, intérprete de árabe, turco y persa en la corte de Felipe III', in Boletín de la Real Academia de la Historia, 211/2: 357-375.

García-Arenal, Mercedes (2006a), 'El entorno de los plomos: Historiografía y linaje', in Barrios Aguilera/García-Arenal (eds), 51-78.

García-Arenal, Mercedes (2006b), 'De la autoría morisca a la antigüedad sagrada de Granada, rescatada al Islam', in Barrios Aguilera/García-Arenal (eds), 557-582.

García-Arenal, Mercedes (2009), 'The Religious Identity of the Arabic Language and the Affair of the Lead Books of the Sacromonte of Granada', in Arabica, 56/6: 495-528. 
García-Arenal, Mercedes and Fernando Rodríguez Mediano (2010), Un Oriente español: Los moriscos y el Sacromonte en tiempos de Contrarreforma, Madrid: Marcial Pons Historia.

García-Arenal, Mercedes, and Fernando Rodríguez Mediano (2013), The Orient in Spain: Converted Muslims, The Forged Lead Books of Granada, and the Rise of Orientalism, Leiden/Boston: Brill.

García López, Aurelio (1995), 'Moriscos Andalusíes en Pastrana. Las quejas de una minoría marginada de Moriscos, con noticias sobre su paralelismo en el Reino de Granada', in Sharq al-Andalus, 12: 163-177.

Gaspariño, Sebastian (2010), Amuletos de al-Andalus 〈http:www.amuletosdealandalus.com> (last accessed on 14 February 2020).

Gozalbes Cavioto, Carlos (2005), 'Un ensayo para la catalogación de los amuletos de plomo andalusíes', Boletín de Arqueología Medieval, 12, 7-18.

Hagerty, Miguel José (1991), 'La traducción interesada: El caso del marqués de Estepa y los libros plúmbeos', in Homenaje al Prof. Jacinto Bosch Vilá, Granada: Universidad de Granada, vol. 2, 1179-1186.

Harris, A. Katie (2007), From Muslim to Christian Granada: Inventing a City’s Past in Early Modern Spain, Baltimore: Johns Hopkins University Press.

Harris, A. Katie (2019), 'Material and Textual Forgeries in the Lead Books of Granada', in Walter Stephens, Earle A. Havens, and Janet E. Gomez (eds), Literary Forgery in Early Modern Europe, 1450-1800, Baltimore: Johns Hopkins University Press, 215-226.

Harvey, Leonard and Gerard Wiegers (2011), 'The translation from Arabic of the Sacromonte tablets and the Archbishop of Granada: an illuminating correspondence', in Vega García Ferrer et al. (eds), 59-78.

Jones, Mark (1992), 'Introduction: Do fakes matter?', in Mark Jones (ed.), Why Fakes Matter: Essays on Problems of Authenticity, London: British Museum Press, 7-12.

Krasner Balbale, Abigail (2019), 'Magical words: Arabic amulets in Christian Spain', in Suzanna Ivanič, Mary Laven, and Andrew Morrall (eds), Religious Materiality in the Early Modern World, Amsterdam: Amsterdam University Press, 211-228.

Imamuddin, S. M. (1981), Muslim Spain 711-1492 A.D. A Sociological Study, Leiden: Brill. Labarta, Ana (1982-1983), 'Supersticiones Moriscas', in Awrāq, 5-6: 160-190.

Macías Rosendo, Baldomero (1995), 'De nuevo sobre Arias Montano y los libros plúmbeos de Granada', in Miscelánea de estudios árabes y hebraicos. Sección Arabe-Islám, 44: 55-67.

Magnier, Grace (2006), 'Pedro de Valencia, Francisco de Gurmendi y los Plomos de Granada', in Barrios Aguilera/García-Arenal (eds), 201-216.

Martínez Enamorado, Virgilio (2002-2003), 'Una primera propuesta de interpretación para los plomos con epigrafía árabe a partir de los hallazgo de Nina Alta (Teba, provincia de Málaga)', in al-Andalus Magreb, 10: 91-127.

Martínez Medina, Francisco Javier (2015), Cristianos y musulmanes en la Andalucía moderna. La Granada del siglo XVI, una ciudad intercultural: Invenciones de reliquias y libros plúmbeos, $\mathrm{PhD}$ thesis, Universidad de Granada, Granada.

Rodríguez Mediano, Fernando and Mercedes García-Arenal (2006), 'De Diego de Urrea a Marcos Dobelio, Intérpretes y traductores de los Plomos', in Barrios Aguilera/GarcíaArenal (eds), 297-334.

Roisse, Philippe (2006), 'La historia del Sello de Salomón. Estudio, edicíon crítica y traducción comparada', in Barrios Aguilera/García-Arenal (eds), 141-172. 
Sánchez Gallego, Rubén and Manuel Espinar Moreno (2017), 'Simbología y decoración de los amuletos del molde islámico de Lorca (Murcia). ¿Unos posibles Pinjantes?’, in Estudios sobre Patrimonio, Cultura y Cencias Medievales, 19: 1299-1326.

Urquízar-Herrera, Antonio (2017), Admiration and Awe: Morisco Buildings and Identity Negotiations in Early Modern Spanish Historiography, Oxford: Oxford University Press.

van Koningsveld, Pieter S. and Gerard Wiegers (2003), 'The parchment of the "Torre Turpiana": the original document and its early interpreters', in Al-Qantara, 24/2: 327-358.

van Koningsveld, Pieter S. and Gerard Wiegers (2019), The Sacromonte Parchment and Lead Books: Critical Edition of the Arabic Texts and Analysis of the Religious Ideas: Presentation of a Dutch Research Project, Granada, 19 March 2019, 19.00-21.00 hours. With Images of the Original Lead Books and the Parchment, [Rijswijk]: Avondrood.

Vega García Ferrer, María Julieta, María Luisa García Valverde, and Antonio López Carmona (eds) (2011), Nuevas aportaciones al Conocimiento y Estudio del Sacro Monte, IV Centenario Fundacional (1610-2010), Granada: Fundacíon Euroárabe.

Wiegers, Gerard (2006), 'Nueva luz sobre Alonso de Luna, alias Muḥammad b. Abī al-'Āsī y su proceso inquisitorial (1618)', in Barrios Aguilera/García-Arenal (eds), 403-418.

Woolard, Kathryn (2006), 'Bernardo de Aldrete, humanista y laminario', in Barrios Aguilera/García-Arenal (eds), 271-282.

\section{Appendix 1: Chronology of the finds}

This list was compiled by combining the information given by F. J. Martínez Medina (Martínez Medina 2015, 117-133), M. García-Arenal and F. Rodríguez Mediano (García-Arenal/Rodríguez Mediano 2013, 23-24, n. 11), and E. Drayson (Drayson 2013, 242-244). ${ }^{62}$

\section{March 1588}

A lead box was found among the rubble of the Turpiana Tower. It contained the following:

- $\quad$ an image of St Mary dressed in an Egyptian way

- a triangular piece of cloth (attributed to the veil of St Mary),

- a bone (attributed to St Stephen)

- a written parchment (prophecy of St John in the encrypted text in Spanish, but written in Greek and Latin letters; comment on the prophecy by

62 Martínez Medina follows the description and titles that Adán Centurión, Marquis of Estepa, provided in his Información para la historia del Sacro Monte, published in Granada in 1632. Drayson uses the Latin titles quoted by L. P. Harvey derived from a manuscript in the National Library of Spain (Madrid, BNE, 6.637); she also translated them into English. The titles and even number of the books do not always coincide, as already mentioned by the same scholars. 
St Caecilius in the encrypted text in Arabic; notes in Arabic by Caecilius and others concerning the prophecy and its author; report by Patricius in Latin concerning the circumstances of the imminent martyrdom of St Caecilius and the hiding and contents of the lead box) (see Fig. 1).

\section{November 1594}

Beginning of the excavations in the caves of Mount Valparaíso (then Sacromonte).

\section{February 1595}

A folded rectangular sheet of lead was found in the caves, inscribed in Latin and identifying the remains of St Mesitón.

\section{March 1595}

Another folded rectangular sheet of lead was found in the caves, which was also inscribed in Latin and identified the remains of St Hesychius.

\section{March-9 April 1595}

Bones, teeth and human ashes were found in the caves.

\section{April 1595}

A folded half-moon-shaped sheet of lead inscribed in Latin was discovered in the caves, which identified the remains of St Ctesiphon.

\section{April 1595}

Human ashes and bones were found in a mass of quicklime in the caves.

\section{April 1595}

A Lead Book with five leaves was found underneath a stone in one of the caves: the Liber Fundamentorum Fidei (The Fundamentals of the Faith) by Ctesiphon (Fig. 4).

\section{April 1595}

A Lead Book with three leaves was discovered in the caves underneath a stone: the Liber de Essencia Veneranda or De Essencia Dei (On the Essence of God) by Ctesiphon (Fig. 3, left).

\section{April-1 May 1595}

Human ashes and a bow-shaped sheet of lead inscribed in Latin were discovered 
in the caves, the latter identifying the remains of St Caecilius, Septentrius and Patricius.

\section{September 1595}

A Lead Book consisting of six leaves was found in soil taken out of the caves: the Oratio et defensivum Iacobi (Prayer and Defence of James the Apostle).

\section{October 1595}

Another Lead Book containing seven leaves was found in soil taken out of the caves: the Liber Ordinationis Missae Jacobi Apostoli or Liber modi [celebrandi] Missam a Iacobi Apostolo (On the Ritual of the Mass of James the Apostle) by Ctesiphon.

\section{October 1595}

A Lead Book containing twelve leaves was discovered in soil taken out of the caves: the Liber excelentis beati Apostoli Iacobi (Book of the Excellent Blessed Apostle James) by Ctesiphon, also known as the Catecismo mayor (Large Catechism). It also contains the Planctus Petri Apostoli Vicarii post negationem Domini nostri (Lament of Peter, Apostle and Vicar, after the Denial of Our Lord) by Ctesiphon.

\section{November 1595}

A Lead Book with twenty-one leaves was found, probably in a cave again: the Liber bonorum actorum Domini nostri Jesu et Virginis Mariae or Liber rerum preaclare gestarum Domini nostri Jesu et Virginis Mariae (Book of the Famous Deeds of Our Lord Jesus and the Virgin Mary) by Ctesiphon.

\section{January 1596}

A Lead Book containing ten leaves was found in soil taken out of the caves: the Liber Assequibilium Divinae Potentiae et Clementiae (Book of Knowledge of the Divine Power and Mercy) by Caecilius.

\section{April 1596}

A Lead Book containing twelve leaves was discovered in soil taken out of the caves: the title is actually unknown, but it is sometimes called the Catecismo menor (Short Catechism). 


\section{August 1597}

Four Lead Books containing a total of twenty-one leaves were discovered in the same cave where the ashes of St Caecilius were found:

- Pars altera Liber Assequibilium Divinae Potentiae et Clementiae (Book of Knowledge of the Divine Power and Mercy: Part Two) by Caecilius; eight leaves

- Liber historiae sigili Salomonis or Liber historiae signis Salomonis (Book of the History of the Seal of Solomon) by Caecilius; three leaves

- Liber relationis Doni Domus Pacis et Tormenti Domus Vindictae (Book of the Story of the Gift of the House of Peace and of the Torment of the House of Vengeance) by Caecilius; four leaves ${ }^{63}$

- De Natura Angelis et eius Potentia (On the Nature of the Angels and Their Power) by Caecilius; six leaves.

\section{September 1597}

A Lead Book with eighteen leaves was found in the same cave where the ashes of St Caecilius were discovered: the Liber sententiarum circa Fidem or Liber sententiarum erga legem et directionem (Book of Sayings on Faith) by Caecilius (Fig. 3, right).

\section{September 1597}

Three Lead Books were found in the soil at the bottom of a ravine:

- the Liber Certificationis Evangelii (Book of the Certification of the Gospel), also known as the Libro de la verdad del Evangelio (Book of the Truth of the Gospel), Hakikat Lenguil or Libro Mudo (Mute Book); sixteen leaves

- $\quad$ the Liber Historiae Certificacionis Evangelii (Book of the History of the Certification of the Gospel), also known as the Libro de la historia de la verdad del Evangelio (Book of the History of the Truth of the Gospel), by Ctesiphon; number of leaves unknown

- the Liber Colloquii Sanctae Mariae Virginis (Book of the Colloquy of St Mary the Virgin) by Caecilius; twenty-five leaves, the first three of which are all blank.

\section{May 1599}

Two Lead Books with a total of twenty-two leaves were discovered in a black bag in the soil at the bottom of the ravine:

63 Drayson mentions it as the Book of the House of Peace and Torment (n. 12). She failed to notice that this item in Harvey's list coincides with the book appearing in Adán Centurión's translation and Hagerty's edition as Libro de la Relación del Don del Lugar de la Paz. 
- the Liber donorum praemii Certificationem Evangelii credentibus (Book of the Rewards to Be Given to Those who Believe in the Truth of the Gospel) by Ctesiphon; number of leaves unknown.

- the Liber Mysteriorum magnorum quae vidit Iacobus Apostulus in Monte Sancto (Book of the Great Mysteries that James the Apostle Saw on the Holy Mountain) by Caecilius; number of leaves unknown.

Possibly discovered in 1599, delivered to King Philip III on 15 December 1606, who finally handed them over to Pedro de Castro in December 1607:

two Lead Books (the same text in two parts) with a total of fifty-one leaves:

- the Liber Rerum praeclare gestarum Iacobi Apostoli or Liber actuum [sic] Iacobi Apostoli (Book of the Deeds of James the Apostle); number of leaves unknown.

- Pars Segunda, Liber Rerum praeclare gestarum Iacobi Apostoli or Liber actuum [sic] Iacobi Apostoli (Second Part of the Book of the Deeds of James the Apostle); number of leaves unknown.

\section{Appendix 2: Biographies of the scholars}

This section focuses on the biographies of the scholars of Oriental languages and experts in Arabic who were involved in the Sacromonte affair. A few other characters have also been added to the list, such as Pedro de Castro, Róman de la Higuéra and Guerra de Lorca, because they are relevant to the general discourse. The names and biographies of the laminarios have not been provided for reasons of clarity and space.

Bernardo de Aldrete (1560-1641) ${ }^{64}$ believed in the authenticity of the finds.

He was canon of Cordoba Cathedral, a renown linguist and the author of the book Del origen y principio de la lengua castellana (1606), in which he demonstrated how the Spanish language was derived from Latin. Despite being subject to ferocious verbal attacks by his opponents, especially by Gregorio López Madera, a devotee of the theory that Spanish was spoken before the Goths, who used the idea to justify the use of the language in the parchment, Bernardo clarified his position in support of the finds in a book called Varias Antiguedades (1614), which was dedicated to Pedro de Castro. In this work, he justified the use

64 Woolard 2006. 
of Spanish in the parchment, which he said was due to the gift given to the Apostles of being able to speak every language on Earth, even those that would only be spoken in the future. This way, the scholar could defend his academic hypothesis while supporting the religious authenticity of the finds. Did he truly believe in the finds or did he support them because it was convenient to? Considering his correspondence with Pedro de Castro and Cristóbal de Aybar - the secretary of the Archbishop - and his publications and reasoning, it is possible that he decided to vouch for the Sacromonte finds because of the pressure and discrediting he was subjected to by the laminarios and the economic assistance he received from the Archbishop. He never changed his official position, even after Pedro de Castro's death. From 1618, he defended the finds in the name of the Archbishop in Madrid. Despite his stance and the help he gave to the cause, he was never allowed to study the originals. He complained about this several times in his letters; he believed that the truth could only be found by making the books' contents readily available for examination, possibly in Latin, and as a result of the scholarly discussion about them. Perhaps he was not allowed to study the books precisely because of this attitude or for fear he might change his mind about them.

Benito Arias Montano (1527-1598) ${ }^{65}$ did not believe the finds were genuine.

A humanist and librarian at the El Escorial Library, he studied languages at the University of Alcalá de Henares (Latin, Greek, Hebrew, Arabic and Syriac) and attended the Council of Trent as an expert in Theology at the request of Martín Pérez de Ayala, Bishop of Segovia. He wrote the Polyglot Bible of Antwerp, best known as the Biblia Regia published in 1572. This work and Montano himself were denounced to the Inquisition for the significant differences between the Biblia Regia and the previous Polyglot Bible and the Vulgate. The charges were finally rejected in 1580 .

Pedro de Castro asked for Montano's opinion on the parchment from the Turpiana Tower and later the Lead Books. He tried not to get involved in the Sacromonte affair, possibly due to his experience with the Biblia Regia, excusing himself because of his poor health. However, he did express his doubt about the antiquity and authenticity of the artefacts (the parchment, books and lead sheets) in various letters he sent to the Archbishop and the Chapter of the cathedral of Granada in 1593 and the following years, although he refused to be more specific concerning the authenticity of the relics and, indeed, on the entire matter. He saw the original piece of parchment in 1593 when Miguel de Luna and Pedro Guerra

65 Cabanelas 1969-1970; Macias Rosendo 1995. 
de Lorca, who both worked for Pedro de Castro, took it to Seville where Arias Montano was living. Pedro de Valencia was also present during the analysis of the artefact. Arias Montano also received copies of the Lead Books and the lead sheets in 1596 (in particular some prints taken directly from the originals), but he could not read them because of the bad quality of the printing. In the following years, he was contacted again by the Archbishop regarding the translation of specific terms.

Ignacio de las Casas (c. 1550-1608) ${ }^{66}$ initially believed the finds were genuine, but rejected their authenticity later.

A Morisco and Jesuit from Granada, he supported the evangelisation of Moriscos through preaching to them in Arabic and was firmly against their expulsion. In 1581, after his brother had refused to adopt the Catholic faith and fled to Morocco, he was called to Rome where his own belief was found to be genuine. Thanks to his knowledge of Arabic, he was asked to participate in a mission to the Middle East (1583-1584), where he made contact with Christian Oriental Churches. He attended several Spanish universities in order to study Theology and finally returned to Granada in 1597. He worked on the translation of the first Lead Book, The Fundamentals of the Faith, and had a favourable opinion of it. However, when he worked on other books, he changed his mind and, after a confrontation with Pedro de Castro in March 1598, he fled Granada in haste, leaving his transcriptions and translations behind. Despite losing his material, he wrote several negative reports and letters about the finds to the Inquisition, the Nuncius and even the Pope, the last of which dates to 1607 . He was pressured by the clergy in Granada and the Jesuit Order to recant his opinion and was even accused of being a crypto-Muslim, but he remained adamant in his stance.

Alonso del Castillo (c. 1520-1607/1610) ${ }^{67}$ believed in the authenticity of the finds apparently, but he may, in fact, have been one of the forgers.

A Morisco, he was the son of the pharmacist Castillo el viejo, probably Hernando del Castillo Acahal (the apothecary), and studied to be a doctor. During the Alpujarras War, he was employed as a translator and a spy. Despite having some friends among the rebels, he forged letters to persuade them to surrender. He was awarded the position of royal translator in 1583, possibly thanks to his role during the war. He also had friends in the Muley family and was described

66 Benítez Sánchez-Blanco 2006b.

67 Cabanelas 1991; García-Arenal/Rodríguez Mediano 2013, 95-120; Drayson 2013, 55-67. 
as a servile man who spent his entire life trying to be accepted as a good Christian, partly to avoid expulsion.

Luis de Marmól believed that del Castillo was involved in the Sacromonte forgeries, as the former had noticed certain similarities between the prophecy written on the parchment from the Turpiana Tower and the jofores, prophecies circulating among the Moriscos during the Alpujarras War, which Alonso had translated into Spanish. According to Marmól, Alonso even predicted there would be finds in the Turpiana Tower, reporting the words of an Alpujarras rebel called el-Meriní. His behaviour was suspicious, too. Alonso had some experience in classical Arabic, but he mainly knew the local dialect. Nonetheless, he declared under oath that the language employed in the forgeries was ancient and not written in any dialect. This is not the case, however, as we know from scholars who studied them in the past and present-day research. On the other hand, despite knowing about the finds in the Turpiana Tower beforehand and the content of the jofores that inspired the prophecy written on the parchment, Alonso was unable to translate its text completely. Perhaps he was merely one of Miguel de Luna's accomplices or he learnt about the forgeries and decided not to expose them, as he understood what benefits they could have for his community. This second hypothesis seems more plausible to me than the first one, since Alonso behaved in a similar manner when translating the Alhambra inscriptions and a banner in Cordoba. In both cases, he changed or avoided translating all the expressions that could be related to a religious context, possibly in order to preserve the artefacts from certain destruction if they were recognised as being Islamic. This hypothesis is corroborated by the opinion he had of the other translator: in a letter sent to the Inquisition in 1600, Alonso wrote that Miguel de Luna was a morisco de los de contrabando, 'from the other side', which possibly means the Muslim side.

Pedro de Castro (1534-1623) ${ }^{68}$ believed the finds were genuine.

He was a scholar, jurist and priest. He studied Philosophy, Hebrew, Greek, and Canonical and Civil Law at the Universities of Salamanca and Valladolid. His father was the Governor of Peru, and when the latter was imprisoned and accused of embezzlement, Pedro de Castro defended him and managed to get him cleared of all charges. In 1561, he was ordained a priest and came to hold several offices, some of which were in Granada, before he was appointed archbishop there in

68 Barrios Aguilera/García-Arenal 2006, 28-50; Barrios Aguilera 2011, 27-197; GarcíaArenal/Rodríguez Mediano 2013, 21-30; Drayson 2013, 114-134. 
1589. This experience made him familiar with the city and its 'Morisco problem'; he was not particularly in favour of them.

When the lead relics started to be found, he understood how important they would be for Granada and therefore promoted their examination. He also had the Lead Books translated by several scholars for the same reason - against the direct orders of the papacy.

De Castro spent all his money and credibility in this quest, and according to Tribaldo de Toledo, Marco Dobelio, al-Hajarī and others, he and his followers discredited or bribed anyone whose opinion undermined his efforts. ${ }^{69}$ Moreover, he supervised the translations made by Castillo and Luna, suggesting them alternative readings for those passages that sounded unorthodox to him. It was also he who reported Pedro de Valencia and his circle to the Inquisition in 1618.

Some years before that happened, he founded the Abbey of Sacromonte over the holy caves in 1609, but in 1610 he was appointed Archbishop of Seville. This event can be regarded as a promotion to a bigger and richer city, but could also hide the attempt to remove him from Granada, the Sacromonte affair and the control over the Lead Books.

In fact, Castro believed that the finds belonged to Granada: he was very selective concerning access to the books and disobeyed both the Pope and the King when they ordered him to send the artefacts to Rome and Madrid respectively. Did he know that the books were forgeries and was afraid they would be dismissed once they were in different hands? Or did he simply consider himself to be essential for the books' positive reception in such distant environments? These questions so far remain unanswered, but it is unlikely that he participated in the forging process.

Marco Dobelio Citerone (c. 1572-before 1654$)^{70}$ rejected the authenticity of the finds, then he changed his mind about them, eventually returning to his initial stance.

Also known as Marco d'Obelio and Marcos Obelio, he was a Kurdish Orientalist and professor of Arabic at La Sapienza University in Rome from 1604 to 1610. He was also in contact with the Academy of Lincei in Rome. Canon Juan de Matute, Pedro de Castro's delegate to Rome, tried to persuade him to move to Granada and work on the Sacromonte finds. Although reluctant at first, in 1610

69 The stories were reported by Luis Tribaldo de Toledo in an exchange of letters with the Marquis of Estepa in 1633. See Harvey/Wiegers 2011.

70 Rodríguez Mediano/García-Arenal 2006, 323-324; García-Arenal/Rodríguez Mediano 2013, 245-268. 
he accepted the request of Bernardo de Sandoval y Roja, the Cardinal of Toledo, confessor of the King and General Inquisitor.

This acceptance may have been motivated by the problems he was experiencing in Rome due to his rivalry with an older colleague, Giovan Battista Raimondi, a sponsor of the Tipografia Medicea Orientale. Or perhaps, but less likely, he was sent on a secret mission by Pope Paul V.

Dobelio followed Pedro de Castro in Seville, where he translated the parchment and several of the Lead Books. When he declared that the Lead Books were not authentic, the Archbishop dismissed him from the task without paying him his promised salary, questioning his competence. Dobelio sued Pedro de Castro for this and became desperate to leave Spain for England, as he wrote to Isaac Casaubon, the Genevan scholar, in 1613. Unfortunately, his plan did not work out. In order to solve his economic problems, he recanted his position on the finds and was paid 100 escudos by Pedro de Castro (according to Luis Tribaldo de Toledo). ${ }^{71}$ During the time he stayed in Spain, he worked as a private teacher (the Marquis of Estepa and possibly Francisco de Gurmendi were among his students), made a list of the Arabic books at El Escorial Library and collaborated with the Inquisition, enjoying its protection. In 1623, he petitioned the King for the position of translator, which had been vacated by both Diego de Urrea and Francisco de Gurmendi, although no existent sources confirm that he got it.

Among his scholarly achievements, Marco Dobelio translated a work of medicine, an Arabic grammar and part of the historical book written by Abū l-Fidā', Mukhtașar ta'rikh al-bashar. He also had an important personal library including dictionaries, moral fables, biographies, a copy of the Qur'an and of traditional sayings and texts dealing with religion, and works on grammar, medicine, botany, poetry, geography and history. Thanks to his work for the Inquisition, he was able to get access to a large number of books found in Pastrana on several occasions after the Morisco expulsion (between 1615 and 1622). These books, which are now lost, were of great help in identifying the texts circulating in the Morisco communities and used as reference material for the texts in the Lead Books.

No information is available concerning his death, but it must have occurred before 1654, as that is the date of the letter in which the Marquis of Estepa reported it to his friend Martín Vázquez Siruela. His books and papers were lost despite the attempts to locate them made by Nicolás Antonio and Vázquez Siruela, both connected to the Sacromonte and the circle of the Marquis of

71 The story was reported by Luis Tribaldo de Toledo in an exchange of letters with the Marquis of Estepa in 1633. See Harvey/Wiegers 2011. 
Mondejar, considered to be the core of Spanish Orientalism in the seventeenth century.

Pedro Guerra de Lorca (d. 1597) ${ }^{72}$ believed in the finds apparently, but was possibly involved in the forgery himself.

He was canon of the Cathedral of Granada from 1588 until he died. A convert of Jewish origin, he was the son of a bureaucrat at the Alhambra. Although a graduate of Theology, he was also a well-known poet. In 1586, he wrote Catecheses mystagogicae pro aduenis ex secta Mahometana: Ad Parochos, \& Potestates about the Morisco problem and how to deal with it. In this work, he expressed a sincere desire for the full incorporation of the Moriscos and the saving of their souls. Besides writing the Catechism, he also composed two other texts that are relevant to the debate on the Sacromonte forgeries: Historia de la vida y martirio de San Çecilio y sus seis compañeros llamados los apóstoles de nuestra Hespaña, written in 1584, and Memorias eclesiásticas de la ciudad de Granada, a defence of the finds, undated but probably composed between 1595 and $1597 .{ }^{73}$ Lorca was one of the laminarios and worked together with Archbishop Pedro de Castro. GarcíaArenal and Rodríguez Mediano believe he may have participated in fabricating the Sacromonte forgeries, if not directly, then at least by providing insights about theological doctrines and Church histories.

Francisco de Gurmendi (d. 1621?) ${ }^{74}$ rejected the authenticity of the finds.

He moved from the Basque Country to Madrid when he was very young and he was raised in the house of Juan de Idiáquez, a prominent member of Philip III's court. He learned Arabic with Diego de Urrea and possibly also with Marco Dobelio, and was appointed translator for the Crown in 1603. When the library of Muley Zidan was acquired in 1611, he made a first assessment of the collection and translated some of the books. In 1615 he translated the first two Lead Books for the King (The Fundamentals of the Faith and On the Essence of God) in his Libello primero. After the negative critiques he received from Pedro de Castro, he wrote another report, Libello Segundo, in 1617 together with the theological comment by Martín Berrotarán y Mendiola, an ex-Jesuit, expelled from the Society of

72 García-Arenal, 2006b, 572-573, García-Arenal/Rodríguez Mediano 2013, 173-174.

73 Both texts are preserved in manuscripts, the first one in Madrid, Biblioteca Nacional de España, Ms 1499, and the second one in Granada, Archivo de la Abadía del Sacromonte, MS C 48, fols 166-377; García-Arenal/Rodríguez Mediano 2013, 174.

74 Magnier 2006, 203-205, 210-215; García-Arenal/Rodríguez Mediano 2013, 241-244; Floristán 2014. 
Jesus for his opposition to the doctrine of the Immaculate Conception. This report was sent to the Royal Council and then to Pope Paul V. Both Gurmendi and Mendiola were associated with the humanist Pedro de Valencia and their papers were confiscated by the Inquisition in 1618 when the Archbishop of Granada denounced their circle. The Historia apologetica sobre las postradas láminas granadinas ${ }^{75}$ reports that he recanted his opinion on the finds, but suffered a violent death in 1621, which prevented him from publishing his new point of view. No sources confirm this information, however, and since the aforementioned text was composed in the circle of the laminarios, the circumstances of his death and his change of heart are extremely doubtful. The date of his death is plausible, though, since no other documents exist in connection with Gurmendi after 1618.

Aḥmad ibn Qāsim al-Ḥajarī (1569/70-shortly after 1640) ${ }^{76}$ believed the finds were authentic.

Also known by the Spanish name of Diego Bejarano, he was probably part of the Morisco community of Pastrana, a town in the province of Guadalajara in Castile-La Mancha. He travelled far and wide during his life and lived in Madrid, Seville and Granada, and after fleeing Spain in 1599, he stayed in Marrakesh, Paris, Bordeaux, Amsterdam (or Leiden), Tunis and probably Cairo. He worked as a translator, diplomat and eventually as a smuggler and spy for the Saadi sultans of Morocco. He was sent to France by Muley Zidan in 1610 in order to rescue some Moriscos who had been captured and robbed by corsairs who were supposed to take them to Morocco from Spain. He was very sensitive to the Moriscos' situation and became part of a network that helped them to flee from Spain, settle in other countries and even retrieve some of the possessions they had had to leave behind. He was also a scholar and had contact with many European Orientalists of his time (he taught Arabic to Thomas Erpenius, for example).

In his Kitāb Nāṣir al-dīn (1637), al-Hajarī claimed he translated the Turpiana parchment for Pedro de Castro (possibly around 1598). He was then paid to revise the translation by the Archbishop since the clergyman found it too Islamic. AlHajarī asked for permission to see and translate the Mute Book several times, but the Archbishop never allowed it. The linguist only read Spanish translations and Arabic transcriptions of the Lead Books (including those done by Alonso del Castillo) at the end of his life. It was in this late period while he was living in Morocco and Tunis that he wrote his book Kitāb Nāṣir al-dīn and other polemical essays against Christianity.

75 Madrid, Real Academia de la Historia, MS 9/2299; Floristán 2014, 369.

76 García-Arenal/Rodríguez Mediano 2013, 139-153; Drayson 2013, 134-139. 


\section{Juan Bautista Hersonita (end of the sixteenth-beginning of the seventeenth cen-} tury $)^{77}$ rejected the authenticity of the finds, then he changed his mind about them, eventually returning to his initial stance.

Hersonita was born in Hasrum, Lebanon and was initially called Yuhanna alHausabi or al-Hasruni. He eventually became Archbishop of Mount Lebanon. He studied in Rome between 1603 and 1614 and later went to Madrid, where he expressed his opinion that the Lead Books were not authentic. In 1618, while he was part of the group around Pedro de Valencia, he was invited to Seville by Pedro de Castro and changed his mind there after being bribed. According to Luis Tribaldos de Toledo, Hersonita was robbed on his way back to Madrid, an event that caused him to move back to his original negative evaluation of the finds. ${ }^{78}$ His reputation suffered greatly from his conduct, however, and his opinion was no longer deemed trustworthy.

Miguel de Luna (c. 1550-1619) ${ }^{79}$ believed in the authenticity of the finds, but he may actually have been one of the forgers himself.

He was a doctor and a translator, although not much is known about him prior to the Sacromonte affair. He was part of an important Morisco family from Baeza, well integrated among the Christian nobility of the city (his grandfather obtained hidalgo status in 1554), and this is most likely the reason why he avoided expulsion in 1570. In a letter written to the King, he claimed that he had served as a translator during the Alpujarras War, a service that is not (or no longer) documented, however. He wrote a short treatise about the therapeutic virtues of baths and bath-houses ${ }^{80}$ and a book called Historia Verdadera del Rey Don Rodrigo, published in 1592 and reprinted several times. When writing the latter, Luna used a translation of an old chronicle supposedly found in El Escorial Library to give historical value to his beliefs, thereby unwittingly producing a forged document. (The book was only recognised as a forgery in the eighteenth century.) He translated both the Turpiana parchment and the Lead Books and consequently tried to obtain an official acknowledgment of his status in the form of a position as royal translator, which he requested - in vain - in 1584 .

77 Rodríguez Mediano/García-Arenal 2006, 332; Harvey/Wiegers 2011, 65; Florián 2014, 366367.

78 The story was reported by Luis Tribaldo de Toledo in an exchange of letters with the Marquis of Estepa in 1633. See Harvey/Wiegers 2011.

79 García-Arenal/Rodríguez Mediano 2013, 155-193; Drayson 2013, 68-93.

80 The text Tratado de los Baños is included in a letter addressed to the King on 25 May 1592 and is now in Madrid, Biblioteca Nacional de España, MS 6149, fols 292r-294v; GracíaArenal/Rodríguez Mediano 2013, 165-166. 
In fact, Luna and his family were threatened by the expulsion decree announced in 1611, but, thanks to the work he was doing for the Sacromonte, they all managed to remain in Spain. In 1610, he had even submitted the documents required to obtain the personal title of hidalgo, but it took so long to process that he never obtained the title; he died in 1619 before it could ever be granted.

Judging by this picture of him, Miguel de Luna seems to have been the perfect example of an assimilated Christian Arab, yet he is mentioned in papers concerning the trial of Jeronimo de Rojas - a Toledan merchant condemned by the Inquisition in 1601 and burnt as a heretic in 1603 - as a knowledgeable and active crypto-Muslim. In these papers, Luna's interpretation of the texts in the Lead Books is mentioned, which is similar to that of al-Hajarī and contrary to the translation Luna made for the Christian authorities. He was not called to testify at the trial, however, although he continued to visit Toledo until 1607 at least. Possibly his close relations with the city's authorities and the Christian Church shielded him from the Inquisition.

His contemporaries accused him of being one of the forgers of the Sacromonte finds. In particular, Luis de Marmól reported that the idea of the forgeries was conceived by El Meriní, a rebel involved in the Alpujarras War, ten or twenty years before the discoveries were made in the Turpiana Tower and that the soldier's daughter gave the papers in which the plan was explained in Arabic to Miguel de Luna. However, the latter's linguistic knowledge was questioned by his contemporaries and by present-day scholars, as he was familiar with the local dialect of Arabic, but not very well-versed in classical Arabic. In fact, when challenged with authentic old documents written in classical Arabic such as those he had translated in Toledo in 1607, he was unable to interpret them properly and wrongly vocalised the personal names. It seems unlikely, then, that he was able to translate the extremely complicated texts in the parchment and the Lead Books without experiencing the same problems. His ability to translate such esoteric texts might lead one to the conclusion that he already knew their content, probably because he was their author. In fact, the parts in classical Arabic are excerpts copied from traditional Islamic texts, kept together by original material composed in the modern Andalusian Arabic that he was familiar with. Moreover, his circle of friends included a few characters who were involved in the invention of other forgeries and in the defence of the Sacromonte finds, such as Jeronimo Román de la Higuera, Pedro Guerra de Lorca, Joan de Faría and Luis Barahona. The last two were active members of the literary circle of the Granada Venegas and although no document exists today showing Luna's affiliation, it is very likely that he was also part of the group. 
If he was really the forger of the Sacromonte finds, or one of them, Luna's agenda seems to have been much more ambitious than that of the circle of the Granada Venegas: the Lead Books were not only intended to persuade Christian society to accept the Morisco minority, but to induce the Roman Church to include crypto-Muslims themes in the Christian doctrine.

Francisco López Tamarid (c. 1530-1590?) ${ }^{81}$ believed in the authenticity of the finds, but was possibly involved in the forgery himself.

A priest of Morisco origins, prebendary of the cathedral and interpreter for the Inquisition of Granada. He was very active during the Alpujarras War, working for John of Austria. When the latter gained command of the Christian forces, López Tamarid and Alonso del Castillo were working in the same entourage. In 1570, he wrote various reports to King Philip II concerning the situation in Almeria, his hometown, and Granada, in which he stressed the distinction between good and bad Moriscos. He suggested Miguel de Luna should be employed to translate the parchment text and also supervised his work when the latter was commissioned with the task. He wrote a compendium of Arabic terms. There is no other news about him after 1588; he probably died between this date and the discovery of the Lead Books or else he would have been involved.

Luis del Mármol Carvajal (1520-1600) ${ }^{82}$ rejected the authenticity of the finds.

A soldier in Africa, he was captured in Morocco and fought for the Spanish army during the Alpujarras War. He worked with Alonso del Castillo during this period. He was also a famous writer, publishing Descripción General de África (1573) in two volumes - a work including a history of Islam up to the battle of Lepanto and a geographical description of North Africa - along with Segunda parte de la Descripción General de África (1599) and Historia del rebellión y castigo de los moriscos del reino de Granada (1600), possibly the most important chronicle of the Alpujarras War that still exists today. In 1593, Pedro de Castro commissioned him to write a report about the Turpiana finds. He pointed out the similarities between the prophecy written on the parchment and the jofores circulating among the Moriscos rebels during the war, translated by Alonso del Castillo. In various letters he sent to the Archbishop, he alluded to Castillo's and Luna's involvement in the affair.

81 García-Arenal/Rodríguez Mediano 2013, 124-128; Drayson 2013, 76-77.

82 García-Arenal/Rodríguez Mediano 2013, 22, 91-93. 
Juan Bautista Pérez (1534-1597) ${ }^{83}$ rejected the authenticity of the finds.

Archbishop of Segorbe from 1591, he was a renowned Humanist. He studied languages (Latin, Greek, Hebrew and Arabic) at the University of Valencia, where he later taught Hebrew. Being related to the work of Martín Pérez de Ayala, he supported the gradual assimilation of Moriscos and preaching in Arabic, although he considered their expulsion as a viable option in the most extreme cases. Later he worked for Bishop Gaspar de Quiroga. Among other works that he never published, he wrote a Dictionarium arabicum, a dictionary of Arabic, Hebrew and Greek. Since the scholar had already exposed Jerónimo Román de la Higuera's invention of the Chronicon attribute to Flavius Dextrus, the General Inquisitor Jeronimo Manrique de Lara asked his opinion concerning the Sacromonte finds in 1595. He wrote the report, but sent it to Gonzales de Valcárcel instead, who was a royal counsellor, with the aim of circulating it anonymously at court, as he did not think Pedro de Castro's opinion would be changed. The Archbishop got informed nonetheless, thanks to his agents in Madrid, and the two clergymen exchanged several letters about the matter. Juan Bautista Pérez died in 1597, leaving the task of publishing his report rejecting the authenticity of the finds to his successor, Feliciano da Figueroa. As the latter was a supporter of the discoveries, however, the report was never published.

Jerónimo Román de la Higuera (1538-1611) ${ }^{84}$ believed the finds were genuine.

He graduated in Theology and taught Philosophy at the University of Alcalá de Henares until 1562, when he was ordained as a Jesuit. He was born and raised in Toledo in the community of converted Jews living there. He tried to build a glorious and sacred past for his city, promote the integration of his community and link his own genealogy to the Mozarabs - the Arabic-speaking Christians living in al-Andalus - by producing false chronicles and documents. The bestknown example of his forgery work is the Chronicon, a collection of reports attributed to Flavius Dextrus and Maximus, both renowned Latin authors. The main theme in it is that the arrival of St James in Spain was motivated by the Jewish community in Toledo asking the apostles for evangelisation. Higuera created a fake letter in order to attribute the ruins of an ancient temple found in Toledo in 1595 to St Thyrsos's shrine, Thyrsos being one of the Apostolic Men. The shrine was allegedly built by Mozarabs during the Muslim occupation, showing the Christian origin of the city. What is even more important here is the invention of the legend of the cross of Caravaca, published in 1615 under the title of Historia

83 Ehlers 2006.

84 Ecker 2002, 369-372; García-Arenal/Rodríguez Mediano 2013, 195-224. 
del mysterioso aparecimiento de la Santíssima Cruz de Carabaca. It was written by Juan de Robles Corbalán, Higuera's pupil, who confessed that he used documents belonging to his master to write it. The legend says that a friar called Chirinos was allowed to perform Mass by the Arab king. But since he forgot to bring the cross with him, a miracle occurred: a piece of the Holy Cross appeared, which caused the Arab king and his wife to convert to Christianity. Inscriptions in strange letters were written in the room where this miracle took place to remember the fact. The inscriptions were translated by Miguel de Luna, who claimed that they were written in Arabic and confirmed the story. The reproductions of the inscriptions in Corbalán's book show the fraud of the translation. This forgery, most likely conceived by Higuera and Luna, combines the personal interests of Jeronimo Román de la Higuera, who claimed to descend from Chirinos and therefore from the Mozarabs, with those of the Morisco community, showcasing the liberality of the Arab king and his final conversion.

The commonalities of intents and strategies with Luna and the Morisco community can also be seen in the many letters that Román de la Higuera wrote to Pedro de Castro from 1596 onwards in defence of the Sacromonte books. The Archbishop did not accept his support, however, possibly because Higuera's reputation was already questionable at the time.

Diego de Urrea (c. 1560-1615) ${ }^{85}$ rejected the authenticity of the finds, then he declared he had no official position on them, eventually returning to his initial stance.

Urrea was born in the south of Italy, then captured with his mother by Ottoman Turks and raised as a Muslim. Under the name of Morato Aga, he studied at the madrasa of Tlemcen, Algeria. He occupied high posts, in particular as a diplomat in the service of several Ottoman rulers. In 1589, he fled (or most likely was captured by Christians) and reached Sicily, where he was taken under the protection of the Count of Alba de Liste, who recognised his potential. There he learned Latin with the Jesuits. He followed the count to Spain around 1591 and entered into the service of the King as a royal translator of Arabic, Turkish, Persian and Tartar and as a diplomat (he played an important role during the transfer of Larache in 1609). In 1593, he was appointed Professor of Arabic at the University of Alcalá de Henares, but at the same time worked as a translator for the Inquisition in Cuenca and as a cataloguer at El Escorial Library. He composed a history of Spain based on Arabic sources and completed an Arabic dictionary

85 Rodríguez Mediano/García-Arenal 2006, 299-322; García-Arenal/Rodríguez Mediano 2013, 225-241. 
as well, both of which are now lost, and also worked on the Thesauro arávigo en Lengua Castellana, which was never finished.

Urrea was sent to Granada by the King to translate the Lead Books and went there twice for a few months in 1596 and 1597. Since he exposed Luna by revealing that the source of the Historia Verdadera was nowhere to be found in El Escorial, the relationship between the translators was tense. His translation was not to Pedro de Castro's liking, however, the latter claiming the translator was only familiar with vernacular Arabic and highlighting his inability to decipher the small and unusual characters on the lead leaves. Later, though, Castro wanted him back again and tried to win him over to the Sacromonte's cause at any cost. In the end, Urrea received several payments from Pedro de Castro and his agents, but even so, he never worked on the translations any more. In his view, the Lead Books were fabricated, but he was discrete about his position on the matter, only sharing his opinions with a few close friends (among them Luis Tribaldos de Toledo and Lupercio Leonardo de Argensola). He finally managed to return to Italy in 1611, where he joined the circle around the Count of Lemos in Naples. There he established relations with Cardinal Borromeo, for whom he translated some texts, and in 1612 he became a member of the Neapolitan branch of the Academy of Lincei, founded by Cesi in Rome; only there would he express his objections concerning the Sacromonte finds. He probably died in Naples in 1615.

Gonzalo de Valcárcel (end of the sixteenth century) ${ }^{86}$ rejected the authenticity of the finds.

Very little information is available about this man today. We know he was a 'jurisconsult' and lawyer who worked for the Royal Councils (abogado de los reales consejos). He sent a paper he wrote on the relics - Discurso sobre las reliquias - to the Nuncios Monsignor Caetani and to the counsellor Juan de Morillas Osorio, who presented it to the Real y Supremo Consejo de Castilla on 18 May 1595. He was one of the first scholars to reject the authenticity of the finds and the first one to point out how the parchment, lead sheets, relics and Lead Books were inextricably related and therefore all forgeries.

Pedro de Valencia (1555-1620) ${ }^{87}$ rejected the authenticity of the finds.

He was the royal chronicler and general chronicler of the Indies from 1607. He was also a renowned humanist, disciple and colleague of Arias Montano. He was present in 1593 when Miguel de Luna and Pedro Guerra de Lorca took the

86 Benítez Sánchez-Blanco 2006a.

87 Magnier 2006, 201-203 and 209-210. 
parchment to Arias Montano in order to evaluate it. The General Inquisitor Bernardo de Sandoval y Roja, following the orders of Pope Clemens VIII, tasked Pedro de Valencia to write a report on the finds. He consequently wrote Sobre el pergamino $y$ laminas in $1607,{ }^{88}$ exposing them as forgeries. The report was possibly sent to Rome in 1616 together with the translation of two Lead Books made by Francisco de Gurmendi. It circulated in Madrid in 1618 when Pedro de Valencia, Francisco de Gurmendi and Martín de Berrotarán y Mediola joined forces to oppose the supporters of the finds at court. In 1618, the papers this circle wrote, including the report, were confiscated by General Inquisitor Bernardo de Sandoval y Roja, who was a fervent supporter of the Sacromonte finds by then. His health deteriorated rapidly in the last year of his life and consequently he died in 1620.

88 Three manuscripts of this treatise exist: Madrid, Biblioteca Nacional de España, MS 2316, fols 1r-30r; Madrid, Biblioteca Nacional de España, MS 7187, fols 116r-138r; Granada, Archivo de la Abadía del Sacromonte, Leg IV, 2, fols 143r-168; Magnier 2006, 202. 
